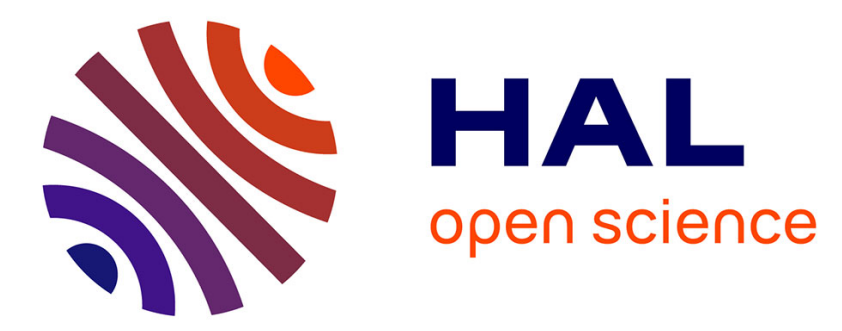

\title{
Analysis and management of stand dynamics of Vietnamese dipterocarp forests by applying a dynamic growth model
}

Thanh Nguyen, Biber, Pretzsch

\section{- To cite this version:}

Thanh Nguyen, Biber, Pretzsch. Analysis and management of stand dynamics of Vietnamese dipterocarp forests by applying a dynamic growth model. Annals of Forest Science, 2012, 69 (5), pp.581-601. 10.1007/s13595-011-0176-x . hal-00930747

\section{HAL Id: hal-00930747 https://hal.science/hal-00930747}

Submitted on 1 Jan 2012

HAL is a multi-disciplinary open access archive for the deposit and dissemination of scientific research documents, whether they are published or not. The documents may come from teaching and research institutions in France or abroad, or from public or private research centers.
L'archive ouverte pluridisciplinaire HAL, est destinée au dépôt et à la diffusion de documents scientifiques de niveau recherche, publiés ou non, émanant des établissements d'enseignement et de recherche français ou étrangers, des laboratoires publics ou privés. 


\title{
Analysis and management of stand dynamics of Vietnamese dipterocarp forests by applying a dynamic growth model
}

\author{
Thanh Tan Nguyen $\cdot$ Peter Biber $\cdot$ Hans Pretzsch
}

Received: 16 June 2011 / Accepted: 22 December 2011 / Published online: 8 March 2012

(C) INRA / Springer-Verlag France 2012

\begin{abstract}
- Context The dipterocarp forests in the Central Highland of Vietnam are threatened by overharvesting. In addition, wildfires frequently affect their dynamics. Sustainable management of this unique forest type is of important concern.

- Aims This study aims at providing a first set of operational information for forest management with a model-based approach. Specifically, we (a) evaluate selected cutting regimes with focus on maximum sustainable yield, (b) explore transformation times from a given to a desired forest state, and (c) preliminarily assess wildfire effects on yield.

- Methods A size class model was developed as a tool to address these issues. Various diameter distributions defined by the $q$ factor concept were used as possible desired equilibrium states to be assessed.

- Results Maximum yields were estimated between 3.9 and $2.7 \mathrm{~m}^{3} \mathrm{ha}^{-1}$ year $^{-1}$, depending on site quality. Based on data from overharvested stands, time for reaching desired equilibria ranged between 20 and 60 years. In stands with
\end{abstract}

Handling Editor: Gilbert Aussenac

Contribution of the co-authors The first author conducted the study in its entirety, from the field work to writing the main body of the text. The second author contributed to model conception and development, data analysis, and manuscript preparation. The third author originally developed the idea of the study, supervised the work, and contributed to the text.

\section{T. T. Nguyen}

Tay Nguyen University,

Buon Ma Thuot, Vietnam

P. Biber $(\bowtie) \cdot$ H. Pretzsch

Chair for Forest Growth and Yield,

Technische Universität München,

Hans-Carl-von-Carlowitz-Platz 2,

85354 Freising, Weihenstephan, Germany

e-mail: Peter.Biber@lrz.tum.de frequent severe wildfires, the long-term yield may decrease by $40 \%$.

- Conclusions Our results suggest the model being an effective tool for simulating effects of treatment alternatives. We conclude that, despite a poor information basis, it is necessary to develop and refine such models for supporting sustainable forest management in Vietnam.

Keywords Dipterocarp forests · Vietnam · Growth model · Scenario analysis · Sustainable forest management - Wildfire effect

\section{Introduction}

Dipterocarp forests in Vietnam cover an area of about 680,000 ha. Ninety-one percent of this area are located in the Central Highlands area and represent a distinct ecosystem. These forests play an important economic and social role as they supply a large amount of high value timber and non-timber products to local people and the country (Con 1991; Dong 2002).

The dipterocarp forests in Vietnam are dry open deciduous forests with the dominant species mainly belonging to the Dipterocarpaceae family (Dong 2002). They differ from dipterocarp forests in other countries in several respects. In general, they are found in areas with less favorable conditions for forest growth, such as poor nutrient supply, waterlogged soils in the rainy season, and drought in the dry season. Their species richness is generally lower compared to other dipterocarp forests. Often there are only one to three locally dominant species accounting for the majority in terms of tree numbers (Diep 1993). The long and hot dry season, coupled with the typically dense ground vegetation and large amounts of litter, regularly leads to wildfires. 
Thus, these forests only consist of dipterocarp species with a thick bark and comparably few other fire-tolerant species.

The Vietnamese dipterocarp forests have been overharvested for a long time in the past. Thus, their diameter distributions pronouncedly show signs of overharvesting. In general, they do not follow the typical inverse J-shape of an uneven-aged forest in equilibrium. In addition, the wildfires decrease both quality and quantity of the recruitment which mainly originates from seed, not from coppice (Diep 1993). Currently, there are mostly young, poor, and degraded forests and very few medium and rich forests in terms of stand volume (Dong 2002). The degraded forests are considered to be of low economic value, and large areas have been transformed into agriculture land or plantations. Therefore, Vietnamese dipterocarp forests are decreasing in both quality and quantity.

Two solutions have been discussed to reduce or stop this loss of natural forests: significant enlargement of the protected forest area and more efficient forest management. Since enlargement of protected forest relates to economic losses, sustainable forest management becomes a more suitable solution (Bowles et al. 1998). Thus, developing tools for defining sustainable forest management in these forests is required, but it faces the challenge to describe the dynamics of these heterogeneous forests in a context of lacking data, in particular permanent plots.

This study proposes a first step in developing a forest dynamics simulation model for supporting practical management. Simulation models have in general turned out to be useful tools for this purpose (Pretzsch 2009, 423 ff.). Among many, the studies, e.g., by Buongiorno and Michie (1980), Lin et al. (1998), and Liang et al. (2005), are typical demonstrations of their use in assessing the effects of different cutting regimes on different stand properties. Several models have been developed and successfully applied to dipterocarp forests in parts of Southeast Asia (Kürpick et al. 1997; Huth and Ditzer 2001; Sist et al. 2003; Köhler and Huth 2004; Huth and Tietjen 2007). Most of them have been used for exploring the effects of different management concepts on growth and yield. These models, however, cannot be transferred to Vietnamese conditions because, as mentioned above, the dipterocarp forests there differ strongly in terms of site conditions and species composition.

Additionally, many of these models need highly detailed input information that is not available to managers in standard application cases. Therefore, we developed a simulation model for dipterocarp forests in the Vietnamese Central Highlands that can sufficiently cover the dynamics of these uneven-aged forests. When creating the model, we took care that the input data needed for working with it can realistically be provided by local practitioners. With this article, we introduce the model and present applications for three issues:

1. Assessing selected cutting regimes with focus on maximum sustainable yield

2. Exploring transformation times needed to come from a given to a desired forest state

3. Preliminary assessment of wildfire effects on long-term growth and yield

\section{Materials and methods}

\subsection{Study area and data}

\subsubsection{Study area}

The study area belongs to the Yok Don National Park which is located at $12^{\circ} 45^{\prime}$ and $13^{\circ} 10^{\prime} \mathrm{N}, 107^{\circ} 29^{\prime} 30^{\prime \prime}$ and $107^{\circ} 48^{\prime} 30^{\prime \prime} \mathrm{E}$. It has an average altitude of about $200 \mathrm{~m}$ above sea level. There is a distinct dry and rainy season each year. The rainy season concentrates between April and October, accounting for about $95 \%$ of the annual rainfall and the dry season is from November to March, with less than $50 \mathrm{~mm}$ rainfall per season in average. Thus, drought and wildfires are the most prominent disturbances. The average annual rainfall is approximately $1,520 \mathrm{~mm}(\mathrm{SD}=279 \mathrm{~mm})$. The average air temperature is highest in April, about $30^{\circ} \mathrm{C}$, while the average temperature is lowest in December with about $22^{\circ} \mathrm{C}$ (Dak Lak Hydrography and Meteorology Station 2007). The soils of the dipterocarp forests are mainly poor soil types such as gray soil, stone and gravel soil, and black basalt soil.

\subsubsection{Research plots}

The data source of the study comprehended 12 1-ha permanent sample plots in the Yok Don National Park established in 1999 and 2004 by the Forest Inventory and Planning Institute of Vietnam. Each plot was quadratic $(100 \times$ $100 \mathrm{~m})$. In the past, the plots were often strongly impacted by overharvesting and wildfires, even though most dipterocarps have a thick, fire resistant bark. Although the national park was founded in 1986, a part of the plots belonged to overharvested areas that were merged into the park in 1991 and 2002 only. Thus, our plots cover quite different degrees of anthropogenic disturbance which represents approximately the range that can be found in the dipterocarp forests all over Vietnam. While Vietnamese forests in general suffered heavily from war damage (Appanah and Turnbull 1998), such damages mainly date from 1970 and earlier. Thus, the current state of the plots mostly results from overharvesting and wildfires. Based on their initial state, the plots were classified into three following status groups: 
heavily disturbed (four plots), moderately disturbed (five plots), and lightly disturbed (three plots). The plots have been re-measured once up to now, 5 years after establishment. At each measurement, all trees of at least $6 \mathrm{~cm}$ diameter at $1.30 \mathrm{~m}$ height were recorded in terms of species, diameter, and survival status (alive, dead). A subset of the trees was taken for height measurements. The number of recruits that grew over the diameter threshold of $6 \mathrm{~cm}$ during the past 5 years was recorded in the second inventory.

Based on biological characteristics and potential height, tree species were categorized into three species groups. Group 1 gathers species with a very similar biological behavior, mainly belonging to the Dipterocarpaceae family. The species of this group are deciduous and typically from the upper main canopy $(>25 \mathrm{~m})$. This group is the most homogeneous one and constitutes a high proportion $(60-80 \%)$ of the total stem number. Group 2 comprises the evergreen tall species that form the lower main canopy $(15-25 \mathrm{~m})$. The tree number of this group accounts for a lower proportion (20-30\%) of the total stem number. Compared with the other two groups, group 3 is the most heterogeneous one. It encompasses all small-sized, lower species belonging to the understorey $(<15 \mathrm{~m})$ combined with non-commercial species (see Table 1 for the main three species of each group and Table 5 in the "Appendix" for the complete species list of the classification, available at www.afs-journal.org). Based on the average height of the 20 biggest trees in each plot, the plots were classified into three site quality levels: good (SQ1), medium (SQ2), and poor site quality (SQ3). Such a site classification by height only in uneven-aged stands was successfully introduced for dipterocarp forests by Sac (1984) and for European selection forests by Flury (1929).

Table 2 presents summary statistics at the stand level for the 12 plots, while Table 3 is for individual trees. A total of 4,975 trees belonging to 64 species were measured, monitored, and recorded in the plots over two measurements. There were 538 new recruits identified on all plots together at the second measurement including 341, 111, and 86

Table 1 Main species of each species group found on the research plots

\begin{tabular}{llll}
\hline No & Scientific name & Family & Species group \\
\hline 1 & Dipterocarpus tuberculatus & Dipterocarpaceae & 1 \\
2 & Dipterocarpus obtusifolius & Dipterocarpaceae & 1 \\
3 & Shorea obtusa & Dipterocarpaceae & 1 \\
4 & Xylia dolabriformis & Mimosaceae & 2 \\
5 & Pterocarpus pedatus & Fabaceae & 2 \\
6 & Adina cordifolia & Rubiaceae & 2 \\
7 & Lumnitzera coccinea & Anacardiaceae & 3 \\
8 & Strychnos nuxblanda & Loganiaceae & 3 \\
9 & Bauhinia purpurea & Caesalpiniaceae & 3 \\
\hline
\end{tabular}

recruits for species groups 1,2 , and 3 , respectively. In the period between both measurements, 233 trees died naturally, which included 156, 53, and 24 dead trees in species groups 1,2 , and 3 , respectively.

\subsection{Methods}

\subsubsection{Model concept}

According to forest growth model classifications by Porté and Bartelink (2002) Monserud (2003), and Pretzsch (2009, pp 423-492), the model we developed in this study is a size class, multi-species model based on statistically fitted systems of difference equations (i.e., the state variables of the model are updated in discrete time intervals). Similar models have been developed for other forest types, e.g., by Lin et al. (1998), Sist et al. (2003), and Liang et al. (2005), for assessing the timber productivity of stands managed under different harvesting regimes. This model approach is well suited for the available data and on the other hand goes well with the information demand and supply of local forest managers. This is because this approach allows to deal with multilayered, uneven-aged forests on the one hand and does not ask for too much input information compared to a single tree model or an ecophysiological growth model. Figure 1 graphically shows the principle of the model. The model comprises 76 diameter classes $N$ for three species groups. At any point of time, the model records the number of trees per hectare $N_{i j}$ in each diameter class, where $i$ stands for the $i$ th diameter class of species group $j$.

The annual change of $N_{i j}, \Delta N_{i j}$ can in general be written as follows (cf. Fig. 1, top left):

$$
\Delta N_{i j}=\text { ingrowth }_{i-1, j}-\text { outgrowth }_{i j}-\text { mortality }_{i j}-\text { harvest }_{i j}
$$

In other words, $N_{i j}$ changes due to ingrowth from the next lower diameter class, outgrowth into the next higher diameter class, mortality losses, and harvest from $N_{i j}$. A special case is the lowest diameter class $N_{1 j}$, where the ingrowth comes from recruitment (cf. Fig. 1, bottom left). The highest diameter class $N_{n j}$ is the other special case as it has no outgrowth and thus contains all trees above a certain diameter (right-opened class). Although an own chain of $N_{i}$ 's is implemented for each species group, the species groups do not develop independently from each other as ingrowth, outgrowth, and mortality depend from species-overarching stand variables (see below).

The class width is $1 \mathrm{~cm}$ for each diameter class. With our generally slow-growing trees, we considered this span an optimal compromise between two necessities: On the one hand, the class width must be sufficiently small because this 
Table 2 Summary stand level statistics by species group for the plots used in this study
$N$ total tree number per hectare at the first measurement, $N_{\mathrm{m}}$ number of mortality trees during the 5 year observation interval, $N_{r}$ number of recruits during the same interval, $B A$ stand basal area, $V$ stand volume at the first measurement

\begin{tabular}{|c|c|c|c|c|c|}
\hline & $N\left(\right.$ trees $\left.\mathrm{ha}^{-1}\right)$ & $N_{\mathrm{m}}\left(\right.$ trees $\left.\mathrm{ha}^{-1}\right)$ & $N_{\mathrm{r}}\left(\right.$ trees $\left.\mathrm{ha}^{-1}\right)$ & $\mathrm{BA}\left(\mathrm{m}^{2} \mathrm{ha}^{-1}\right)$ & $V\left(\mathrm{~m}^{3} \mathrm{ha}^{-1}\right)$ \\
\hline \multicolumn{6}{|c|}{ Species group 1} \\
\hline Mean & 271.3 & 13.0 & 28.4 & 13.3 & 90.5 \\
\hline SE & 35.7 & 2.3 & 2.8 & 1.0 & 9.5 \\
\hline Max & 509.0 & 24.0 & 44.0 & 17.3 & 147.8 \\
\hline Min & 145.0 & 2.0 & 14.0 & 6.3 & 35.2 \\
\hline \multicolumn{6}{|c|}{ Species group 2} \\
\hline Mean & 71.4 & 4.4 & 9.2 & 4.2 & 25.0 \\
\hline SE & 7.1 & 1.1 & 1.0 & 0.3 & 2.1 \\
\hline Max & 136.0 & 14.0 & 15.0 & 6.6 & 39.8 \\
\hline Min & 40.0 & 0.0 & 3.0 & 2.1 & 12.2 \\
\hline \multicolumn{6}{|c|}{ Species group 3} \\
\hline Mean & 27.6 & 2.0 & 7.1 & 0.7 & 2.7 \\
\hline SE & 2.9 & 0.5 & 1.9 & 0.1 & 0.3 \\
\hline Max & 44.0 & 5.0 & 21.0 & 1.1 & 4.8 \\
\hline Min & 9.0 & 0.0 & 1.0 & 0.3 & 1.0 \\
\hline
\end{tabular}

type of model generally relies on the assumption of sufficient homogeneity inside a class (Sterman 2000). On the other hand, the class width has to be wide enough that trees overleaping one or more classes in 1 year are most improbable, a concept first introduced into forest growth models by Usher (1969). The lowest diameter class covers all trees with diameters of at least 6 and less than $7 \mathrm{~cm}$, while the highest class contains all trees with diameters of at least $81 \mathrm{~cm}$, which will be reached only rarely. Technically, the model was implemented with the software VENSIM DSS 5.7a (Ventana Systems 2011).

Table 3 Summary statistics for the individual tree data used in this study

\begin{tabular}{lrll}
\hline & $\begin{array}{l}\text { Diameter } \\
(\mathrm{cm})\end{array}$ & $\begin{array}{l}\text { Tree volume } \\
\left(\mathrm{m}^{3}\right)\end{array}$ & $\begin{array}{l}\text { Diameter growth } \\
\left(\mathrm{cm} \mathrm{year}{ }^{-1}\right)\end{array}$ \\
\hline Species group 1 & & \\
Mean & 21.41 & 0.373 & 0.382 \\
SE & 0.30 & 0.102 & 0.002 \\
Max & 120.40 & 12.041 & 0.781 \\
Min & 6.00 & 0.005 & 0 \\
Species group 2 & & \\
Mean & 23.50 & 0.387 & 0.323 \\
SE & 0.51 & 0.022 & 0.004 \\
Max & 98.60 & 6.184 & 0.693 \\
Min & 6.00 & 0.004 & 0 \\
Species group 3 & & \\
Mean & 15.40 & 0.113 & 0.331 \\
SE & 0.51 & 0.011 & 0.008 \\
Max & 40.20 & 1.673 & 0.682 \\
Min & 6.10 & 0.007 & 0 \\
\hline
\end{tabular}

Tree volume and diameter are the values from the first measurement

\subsubsection{Submodels}

Outgrowth model The annual outgrowth from $N_{i j}$, which is at the same time ingrowth into $N_{i+1, j}$, is calculated as follows:

outgrowth $_{i j}=N_{i j} \cdot$ rout $_{i j}$

where rout $_{i j}$ is a relative annual outgrowth rate that is calculated from the diameter class' mean diameter increment as proposed by Schütz (2006):

rout $_{i j}=\frac{i d_{i j}}{c w_{i j}}$

where $i d_{i j}$ is the annual diameter increment of a mean tree in centimeters per year and $c w_{i j}$ is the class width of diameter class $i j(1 \mathrm{~cm}) . i d_{i j}$ is estimated as follows:

$i d_{i j}=a_{1} \cdot D_{i j}^{b}+a_{2} \cdot D_{i j}+a_{3} \cdot B A+a_{4} \cdot S Q 2+a_{5} \cdot S Q 3$

where

$a_{1} \ldots a_{5}, b$ Species group specific parameters

$D_{i j} \quad$ Class median diameter of class ij in $\mathrm{cm}$

BA Basal area of the whole stand (square meters per hectare), calculated as $B A=\frac{\pi}{4 \cdot A} \cdot \sum_{j=1}^{m} \sum_{i=1}^{n} D_{i j}^{2} \cdot N_{i j}$ with $A=$ stand size in hectares, and $D_{i j}$ converted into $m$ SQ2 1 for site quality 2 and 0 otherwise, SQ3: 1 for site quality 3 and 0 otherwise; thus, if both, SQ2 and SQ3 are zero, the model predicts diameter increment for site quality 1

The model was fitted with the diameter increment data from all repeatedly measured living trees using a non- 


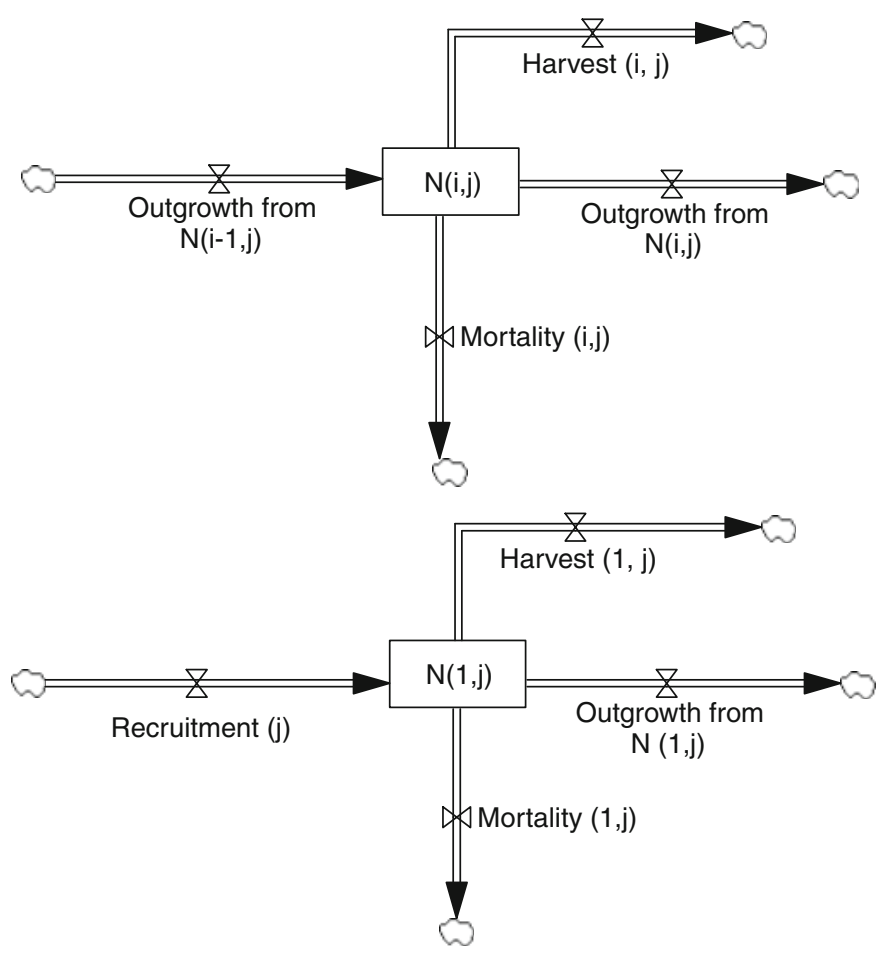

Fig. 1 General model concept. Tree numbers $N$ per diameter class $i$ and species group $j$ (boxes) and their possible changes (arrows). According to the notation conventions of System Dynamics (Sterman 2000), boxes and pipe-like arrows represent state variables and their

linear ordinary least squares multiple regression algorithm assuming i.i.d. errors. The parameter estimates and related statistics of the diameter increment model are listed in Table 4. All parameter estimates had the expected signs and were statistically significant at the 0.1 level.

Mortality model The annual mortality from diameter class $i j$ is calculated as

mortality $_{i j}=N_{i j} \cdot$ pmort $_{i j}$

where pmort $_{i j}$ is a class and species specific annual probability for natural mortality. It is estimated with the following logistic model

pmort $_{i j}=\left(1+e^{-\left(a_{0}+\frac{a_{1}}{i_{i j}}+a_{2} \cdot D_{i j}+a_{3} \cdot D_{i j}^{2}+a_{4} \cdot B A+a_{5} \cdot B A c u m\right)}\right)^{-1}$

where $a_{0} \ldots a_{5}$ are species group specific parameters. BAcum is the cumulated basal area per hectare of all diameter classes higher than $i j$. We fitted the model with a logistic regression algorithm optimizing the maximum likelihood criterion. Table 4 presents all parameter estimates with standard errors and significances. Note that not all of the parameters from Eq. 6 where used if reducing the set of explanatory variables did not weaken the model fit significantly $\left(\chi^{2}\right.$ test). The signs of all parameter estimates are

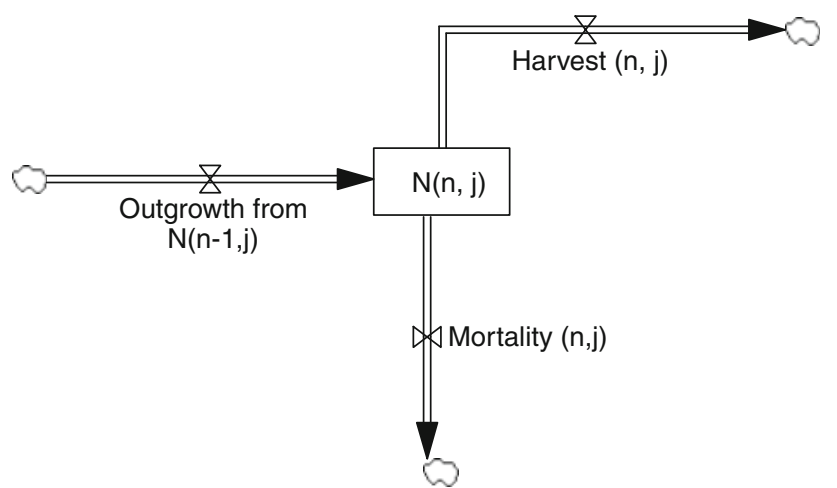

changes, respectively. Top left standard case, bottom left the lowest diameter class, top right the highest diameter class. Illustration made with the Software VENSIM (Ventana Systems 2011)

plausible, even for species group 3 where the number of dead trees was small (24 dead trees) and the species composition was heterogeneous.

Recruitment model Recruitment that is annual ingrowth per hectare in the lowest diameter class is estimated with the same model for all species as

Recruitment $_{j}=a_{0}+a_{1} \cdot N_{j}+a_{2} \cdot B A+a_{3} \cdot S Q 2+a_{4} \cdot S Q 3$

where $N_{j}$ is the total number of trees per hectare belonging to species group $j$ and $a_{0} \ldots a_{4}$ are parameters common to all species groups. Table 4 presents the parameter estimates, obtained with OLS regression. The signs and magnitudes of the estimates are plausible. They reveal a negative effect of stand basal area on ingrowth as described, e.g., by Lin et al. (1998), Kolbe et al. (1999), Zhao et al. (2004), and Liang et al. (2005), as well as higher recruit numbers on better sites.

Simulating harvest For simulating harvest, our model compares the actual diameter distribution of the current stand with a desired diameter distribution that must be given by the user. The model is not limited to any type of distribution as long as it gives a desired tree number $N_{i j}{ }^{\prime}$ for any diameter 
Table 4 Parameter estimates and fit statistics of the major model components diameter increment, mortality, and recruitment (Eqs. 4, 6, and 7) by species group

\footnotetext{
Standard errors are given in parentheses

$R^{2}$ coefficient of determination, $d f$ degrees of freedom

${ }^{\mathrm{a}}$ Significance level at 0.001

${ }^{\mathrm{b}}$ Significance level at 0.01

${ }^{\mathrm{c}}$ Significance level at 0.05

${ }^{\mathrm{d}}$ Significance level at 0.1
}

$R^{2}$

df

\begin{tabular}{|c|c|c|c|c|}
\hline \multirow[t]{2}{*}{ Parameter } & & \multicolumn{3}{|l|}{ Species group } \\
\hline & & Species group 1 & Species group 2 & Species group 3 \\
\hline \multirow[t]{6}{*}{ Diameter increment (Eq. 4) } & $a_{1}$ & $0.1726(0.0057)^{\mathrm{a}}$ & $0.1758(0.0057)^{\mathrm{a}}$ & $0.1758(0.0114)^{\mathrm{a}}$ \\
\hline & $b$ & $0.5587(0.0173)^{\mathrm{a}}$ & $0.4729(0.0281)^{\mathrm{a}}$ & $0.5254(0.0459)^{\mathrm{a}}$ \\
\hline & $a_{2}$ & $-0.0215(0.0014)^{\mathrm{a}}$ & $-0.0144(0.0014)^{\mathrm{a}}$ & $-0.0296(0.0045)^{\mathrm{a}}$ \\
\hline & $a_{3}$ & $-0.0020(0.0004)^{\mathrm{a}}$ & $-0.0015(0.0006)^{\mathrm{c}}$ & $-0.0025(0.0009)^{\mathrm{b}}$ \\
\hline & $a_{4}$ & $-0.0534(0.0034)^{\mathrm{a}}$ & $-0.0401(0.0054)^{\mathrm{a}}$ & $-0.0088(0.0086)^{\mathrm{d}}$ \\
\hline & $a_{5}$ & $-0.0855(0.0033)^{\mathrm{a}}$ & $-0.0854(0.0057)^{\mathrm{a}}$ & $-0.0405(0.0088)^{\mathrm{a}}$ \\
\hline$R^{2}$ & & 0.544 & 0.524 & 0.489 \\
\hline$d f$ & & 2,831 & 740 & 283 \\
\hline \multirow[t]{6}{*}{ Mortality (Eq. 6) } & $a_{0}$ & $-4.0527(0.4817)^{\mathrm{a}}$ & $-7.7813(0.3526)^{\mathrm{a}}$ & $-7.1774(0.6351)^{\mathrm{a}}$ \\
\hline & $a_{1}$ & & $15.5840(2.1428)^{\mathrm{a}}$ & $0.1906(0.8749)^{\mathrm{d}}$ \\
\hline & $a_{2}$ & $-0.1582(0.0329)^{\mathrm{a}}$ & & \\
\hline & $a_{3}$ & $0.0011(0.0007)^{\mathrm{d}}$ & & \\
\hline & $a_{4}$ & $0.0951(0.0199)^{\mathrm{a}}$ & & \\
\hline & $a_{5}$ & & $0.1389(0.0161)^{\mathrm{a}}$ & $0.1493(0.3666)^{\mathrm{a}}$ \\
\hline$R^{2}$ & & 0.470 & 0.527 & 0.136 \\
\hline$d f$ & & 224 & 225 & 225 \\
\hline \multirow[t]{5}{*}{ Recruitment (Eq. 7) } & $a_{0}$ & $4.202(1.611)^{\mathrm{c}}$ & & \\
\hline & $a_{1}$ & $0.017(0.002)^{\mathrm{a}}$ & & \\
\hline & $a_{2}$ & $-0.126(0.033)^{\mathrm{c}}$ & & \\
\hline & $a_{3}$ & $-0.807(0.575)^{\mathrm{d}}$ & & \\
\hline & $a_{4}$ & $-1.731(0.621)^{\mathrm{b}}$ & & \\
\hline$R^{2}$ & & 0.788 & & \\
\hline$d f$ & & 31 & & \\
\hline
\end{tabular}

class $i j$. Thus, the annual number of harvested trees from a diameter class $i j$ (Eq. 1) is calculated as:

harvest $_{i j}=\max \left(0, N_{i j}-N_{i j}^{\prime}\right)$

Volume calculation Although wood volume, neither on diameter class nor on stand level, is no driving variable in the model, it is a highly important model output. The volume calculation in our model is based on upscaling the individual tree volume function of Dong (2002):

$V=-0.08069+0.31144 \cdot D^{2} \cdot H$

where $V$ is the tree's volume (cubic meters), $D$ is diameter at breast height (meters), and $H$ the tree's height (meters). The volume in one diameter class was calculated by inserting the middle diameter of each class and its corresponding height in Eq. 10 and multiplying the resulting volume with the class' tree number. The height for each class was estimated from species group and site specifically fitted height-diameter relationships of the form:

height $=1.3+\left(1 /\left(a+\frac{b}{D}\right)\right)^{3}$
Here, $D$ must be given in centimeters, and the resulting height is in meters. $a$ and $b$ are parameters listed in Table 6 in the "Appendix" (www.afs-journal.org).

\subsubsection{Model evaluation}

The growth model was evaluated before applying it in practice. There are several criteria and methods to evaluate growth models (see Pretzsch et al. 2002; Vanclay and Skovsgaard 1997). As the database of this study is comparably narrow, we did not perform a statistical validation with independent data or by cross validation. In contrast, all available data sets have been used to calibrate the model. The first critical evaluation came directly with fitting the model equations when we checked all parameter estimates for plausible signs and orders of magnitude. A bias-free fit was an important criterion for accepting a fitted equation.

Apart from that, two types of quantitative validation were conducted in this study. Firstly, short-term forecasts on the calibration plots were calculated for a growth interval of 5 years. Secondly, long-term steady states predicted with the model were checked for quantitative and qualitative plausibility. 
For the short-term validation, the growth model was used to predict the state of each plot in terms of basal area and diameter distribution after 5 years, given its initial state. The results were then compared to the observed values. For the long-term evaluation, the model was applied to simulate the development of a stand in terms of basal area and diameter distribution evolution without harvest over 1,000 years.

\subsubsection{Model applications}

Maximizing sustainable yield at steady state For this application, we start and keep stands in equilibrium at different densities by harvesting. The goal is to find stand stocking levels (in terms of basal area) and diameter distributions that maximize the sustainable yield, more precisely, the average annual harvesting volume during simulation time.

As equilibrium distributions, which define the stand of interest's initial state as well as the desired state that must be supported by harvesting (see Eq. 8), we use geometric progressions of stem numbers with tree diameter as they are widely accepted as ideal for uneven-aged stands even though this assumption may be questioned (Chevrou 1990). Geometric diameter distributions are defined by a constant ratio $q$ between the tree numbers of adjacent diameter classes $\left(q=N_{i+1, j} / N_{i j}\right)$. In practice, their definition by choosing a value for $q$ is often referred to as the " $q$ factor method" which is frequently applied to uneven-aged forests (Alexander and Edminster 1977; Lu and Buongiorno 1993; Lin et al. 1998, among others). In addition to $q$, the total basal area and the maximum diameter must be given.

Each equilibrium distribution scenario was therefore defined by a value triplet of maximum diameter, total basal area, and $q$. Based on biological species characteristics, the maximum diameters were set as follows: for site quality 1 $70 \mathrm{~cm}$ for species groups 1 and 2, and $35 \mathrm{~cm}$ for species group 3 . The maximum diameters for site quality 2 were $60 \mathrm{~cm}$ for species groups 1 and 2, and $35 \mathrm{~cm}$ for species group 3. For site quality 3 , the maximum diameters of species groups 1 and 2 were $50 \mathrm{~cm}$, and $35 \mathrm{~cm}$ for species group 3.

Equilibrium basal area varied from 7.5 to $30 \mathrm{~m}^{2} / \mathrm{ha}$ in steps of $2.5 \mathrm{~m}^{2} / \mathrm{ha}$. The proportion of the basal areas between species groups was fixed to the average of all sample plots which was $75 \%, 20 \%$, and $5 \%$ for species groups 1,2 , and 3 , respectively.

Based on the actual state of the dipterocarp forests in Vietnam, we set $q$ to five different values-1.3, 1.4, 1.5, 1.6, and 1.7. Four of these five values were tested in each site quality. So, altogether 120 scenarios were simulated for three site qualities. Simulation time was 100 years with a cutting cycle of 10 years.
Exploring transformation times needed to come from a given to a desired forest state While we explore the sustainable yield of different equilibrium states above, this application wants to find out the time needed to transform the degraded stands typically found in the field into such a sustainable state. As target states, we used the diameter distributions that yielded the maximum sustainable harvest for the three site classes in the previous application. Harvest was again defined as in Eq. 8. We assumed the target state to be reached when the simulated stand was inside a span of $\pm 20 \%$ of the target state in terms of tree number, basal area, and harvestable volume. This range seemed to be reasonable for practical purposes, as in practice, a theoretical ideal can never be fully reached. In addition, the stand properties turned out to change only very slowly when approaching the stationary state. This would lead to practically irrelevant information about transformation times when postulating a very precise match.

Preliminary assessment of wildfire effects on long-term growth and yield A typical characteristic of the dipterocarp forests in Vietnam is that wildfires often occur during the dry season. They often originate from unconcerned activities of the local people and are associated with natural conditions such as a long dry season from November to May and a thick litter layer. The frequency of wildfires varies between annual and quadrennial occurrence (Sac 1984). A study on permanent experimental plots in the dipterocarp forests conducted by Diep (1993) during a period of 3 years indicated that if there were no wildfires, the total number of regeneration trees lower than $2 \mathrm{~m}$ was 9,040 trees/ha, and among them, there were 750 good quality (potential) trees accounting for $8.3 \%$ of the total. After a wildfire occurred to such a stand, the total number of regeneration trees was 5,000/ha and the potential trees still amounted to 150/ha, accounting for 3\% of the total. In stands where wildfires occurred every year, the total amount of regeneration was 3,400 trees/ha, and no potential trees were found.

In our model, wildfires reduce the recruitment that is entering the lowest diameter class (Eq. 7) in a given year by an assumed factor. Although this is a very simplistic and somewhat optimistic approach, as a delay of ingrowth in the years following fire occurrence is not taken into account, it can show trends and give hints for future model development.

Each scenario run started with the average stand state of all 12 plots, assuming the best site quality as it is most relevant for production purposes. As target state, we defined the diameter distribution that had turned out to deliver the maximum sustainable yield on the best sites previously. The simulation time span covered 200 years. 
Wildfire occurrences were varied in terms of intensity and frequency. Intensity comprised four levels, meaning recruitment reductions of $100 \%, 75 \%, 50 \%$, and $25 \%$ per occurrence. Frequency included annual, biennial, triennial, and quadrennial fire occurrences. Thus, together with a control run with no wildfire occurrence, 17 runs were calculated. Goal variable was the average annual yield over the simulation time.

The fire occurrence and recruitment reduction scenarios are intended to cover a realistic range of possibilities. However, most frequently wildfires occur biennially, reducing recruitment by $50-60 \%$ each time (Diep 1993).

\section{Results}

\subsection{Model evaluation}

All submodels could be fitted without bias to the data. The parameters in the diameter increment, mortality, and recruitment models were statistically significant at least at the $5 \%$ level with exception of the parameters connected with the variable SQ2 in the diameter increment model for species group 3 and the overall recruitment model (Table 4). This indicated that there is no clear difference between the effect of site quality 1 and site quality 2 on recruitment. This may be partly explained by the small data set available for recruitment. For the diameter growth, the results suggested that the chosen approach for site quality classification was confirmed for species groups 1 and 2, but not for species group 3. Seemingly, this group was too heterogeneous a set of species to show a consistent relation of diameter increment with site quality. This finding is supported by the fact that competitive or other mutual relationships between different species in mixed stands are complicated as results of Pretzsch and Schütze (2009) show. However, for the purpose of this study, this classification approach was acceptable because the trees in species group 3 typically account for a very low proportion of the total stem number only, so a significant influence on the simulation results is not to be expected.

Comparisons of the difference between observed and predicted basal areas and diameter-class-wise tree numbers for each site quality and each species group after a 5-year growth interval showed only small absolute and relative differences (Tables 7 and 8 in the "Appendix," available at www.afs-journal.org). Paired sample $t$ tests did not reveal any statistically significant differences.

The long-term simulation runs without harvest showed dampened oscillations of basal area within periods of several hundred years (Fig. 6 in the "Appendix," available at www.afs-journal.org). The oscillations result from such forests being feedback systems with long delays (cf. Sterman 2000), e.g., current recruitment numbers start to have a perceptible effect on stand basal area and future recruitment after several decades only, when the former recruits are tall trees. The basal areas remained within plausible values. During several hundred years, the diameter distributions evolved from inverse J-shaped over unimodal into top-heavy patterns and from there back into J-shaped again (Fig. 7 in the "Appendix," available at www.afs-journal.org). Thus, the simulated dynamics of undisturbed stands were consistent with the findings of other studies (Buongiorno and Michie 1980; Lin et al. 1998).

\subsection{Outcomes of the model applications}

\subsubsection{Maximizing sustainable yield at steady state}

The stand level results of a typical scenario simulation (desired basal area $=15 \mathrm{~m}^{2} / \mathrm{ha}, q=1.4$, and site quality=1) are presented in Fig. 2. As with all runs in this application, the stand is kept in equilibrium throughout the simulation. In the presented simulation run the stand produced a sustainable yield of $3.74 \mathrm{~m}^{3} \mathrm{ha}^{-1}$ year $^{-1}$ with a constant stand volume of $108 \mathrm{~m}^{3} \mathrm{ha}^{-1}$.

Figure 3 provides a comprehensive view on the outcomes of all 120 runs. In general, the results show that the sustainable stand yield mostly depends on basal area, but also on the chosen $q$ value. For all three site qualities, the relationship between annual yield and stand basal area followed a similar and pronounced pattern. Very low $\left(<10 \mathrm{~m}^{2} / \mathrm{ha}\right)$ and very high $\left(>25 \mathrm{~m}^{2}\right)$ basal areas lead to a low yield, while intermediate basal areas, roughly around $15-20 \mathrm{~m}^{2} / \mathrm{ha}$, come with the highest productivity (Fig. 3a-c). The sustainable yield at optimum basal area is nearly twice as high as for very low and very high densities. The optimum basal area is found to be decreasing from best to worst site conditions (Fig. 3d), and expectedly, the maximum sustainable yield is the highest on the best site $\left(3.9 \mathrm{~m}^{3} \mathrm{ha}^{-1}\right.$ year $\left.^{-1}\right)$, intermediate on the medium site $\left(3.2 \mathrm{~m}^{3} \mathrm{ha}^{-1} \mathrm{year}^{-1}\right)$, and the lowest on the worst site $\left(2.8 \mathrm{~m}^{3} \mathrm{ha}^{-1} \mathrm{year}^{-1}\right)$. Corresponding optimum basal areas are 20,18 , and $16 \mathrm{~m}^{2} \mathrm{ha}^{-1}$ for site qualities 1,2 , and 3 , respectively. As can be seen from Fig. $3 d$ in addition, the density-productivity curves for the different site qualities never cross.

Figure $3 \mathrm{a}-\mathrm{c}$ also illustrates the effect of the chosen $q$ value on the annual sustainable yield. With the same site quality and basal area, stands with different $q$ values produced different annual yields. The graphs show that when basal area was lower than about $12 \mathrm{~m}^{2} \mathrm{ha}^{-1}$, higher $q$ values were coupled with higher annual yield of the stand. However, this did not hold true for higher basal areas. This may be explained as follows: With the same stand basal area, 
Fig. 2 Results of a simulation run for a stand being kept in equilibrium. a Stand basal area, b stand volume, $\mathbf{c}$ harvested volume, $\mathbf{d}$ simulated diameter distributions at different times
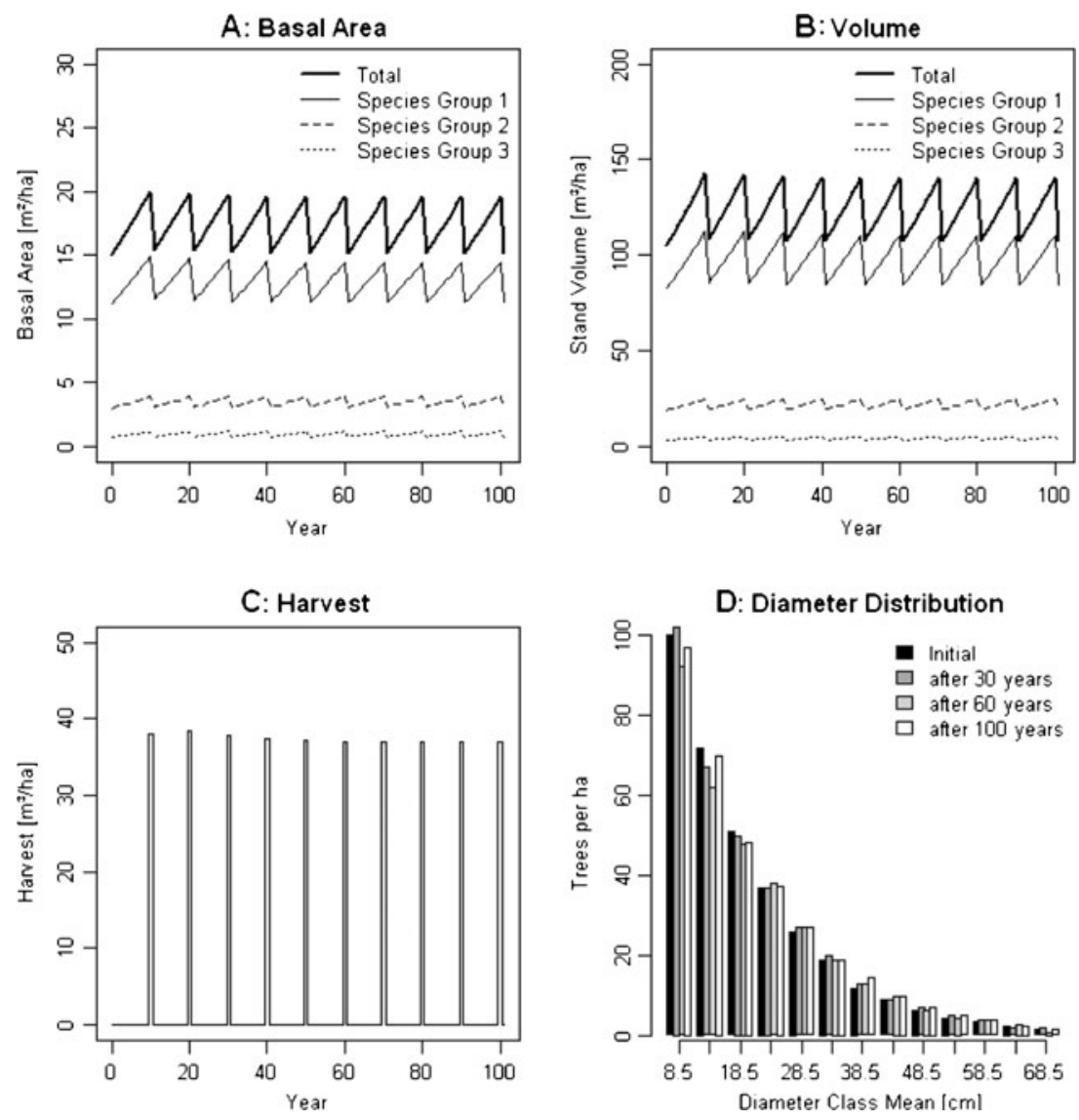

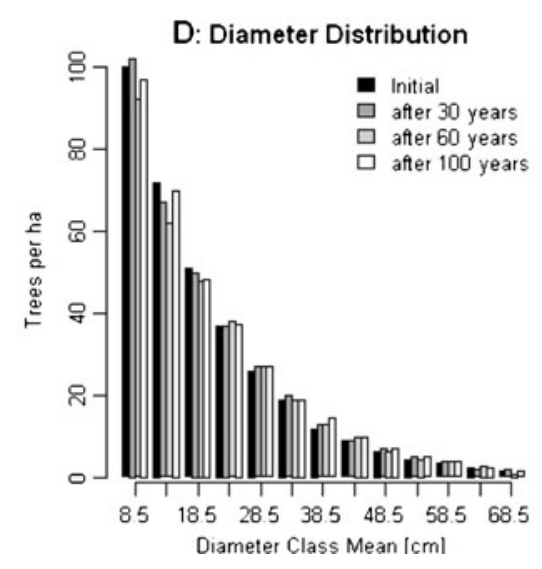

stands with higher $q$ values have higher tree numbers in the small diameter classes. In addition, with low basal areas, overall competition is not strong, leading to a fast tree growth, so that the growth of the stand was approximately proportional to the tree number. However, with higher stand basal areas, competition effects become dominant, especially for the growth of the small trees. The stands on site qualities 1, 2, and 3 that produced the highest yields had $q$ values of $1.4,1.5$, and 1.6, respectively, indicating that a site specific choice of desired $q$ values can be recommended in practice.

From the parameters defined above, the tree number by diameter class of the optimum equilibrium distributions for each site quality can be calculated (see Table 9 and Fig. 8 in the "Appendix," available at www.afs-journal.org). Due to the different $q$ factors, the steepness of the distributions increases from good to inferior site qualities.

\subsubsection{Exploring transformation times needed to come \\ from a given to a desired forest state}

In simulation runs that applied the optimum equilibrium distributions as long-term targets to heavily disturbed stands like plot 8 (illustrated in Fig. 9 in the "Appendix," available at www.afs-journal.org), the number of trees in the small diameter classes up to $19 \mathrm{~cm}$ stayed very low and never reached the target tree number. Obviously, the simple template-like usage of the target distributions as shown above could not avoid a shortage of recruitment, especially on site quality 3 where the target distribution demands for very high tree numbers in the small diameter classes.

In order to maintain higher numbers of trees in the small classes (up to $19 \mathrm{~cm}$ ), these classes were excluded from harvesting, while the higher classes were still harvested with the target distribution as a guideline. With this modification, regulation toward the target distributions turned out to be possible. An extreme example is plot 8. This stand had a very low initial basal area of $10.2 \mathrm{~m}^{2} /$ ha. Under the described harvesting scheme, the basal area, volume, and diameter distribution reached a steady state after approximately 50 years, which meant five cutting occurrences. Consequently, the harvested amounts became stable from year 60 on (see Fig. 10 in the "Appendix," available at www.afs-journal.org).

As can be taken from Fig. 4, the transformation time found for all 12 plots ranged from 20 years (plot 12) to 60 years (plots $2,8,10$, and 11), depending on how heavily disturbed the stand initially was. Heavier disturbed stands tend to have a lower initial basal area; however, there are also stands with basal areas of more than $20 \mathrm{~m}^{2} /$ ha which were classified as moderately and heavily disturbed (Fig. 4). 
Fig. 3 Simulated long-term mean annual volume increment $(M A I)$ obtained with different basal areas and $q$ values. a Site quality 1 , b site quality 2 , c site quality 3 , d optimal curves (the highest peak) from each site quality
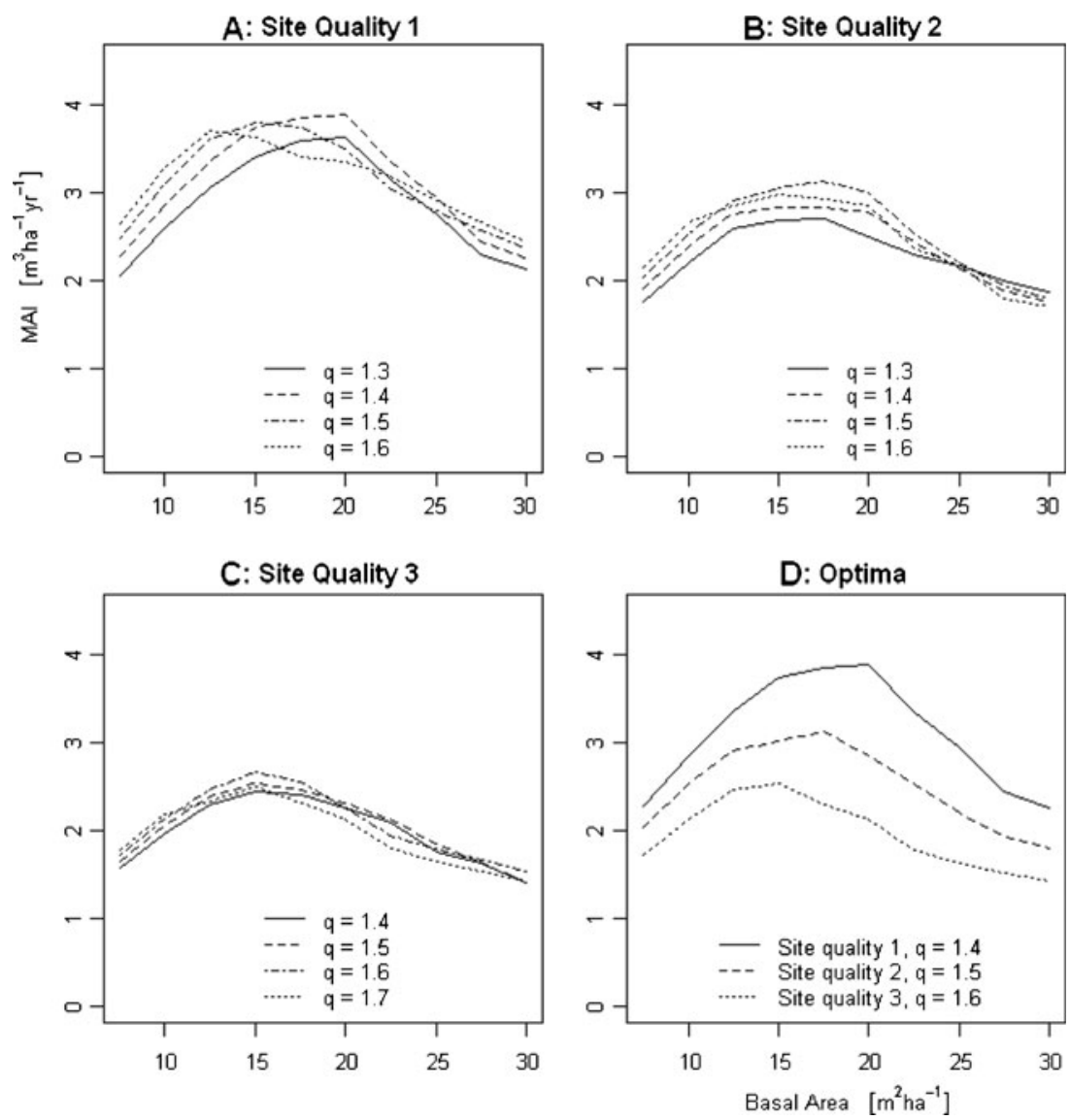

These stands show long transition times of 50 and 60 years, indicating that basal area alone is not a sufficient indicator for closeness to a sustainable equilibrium.

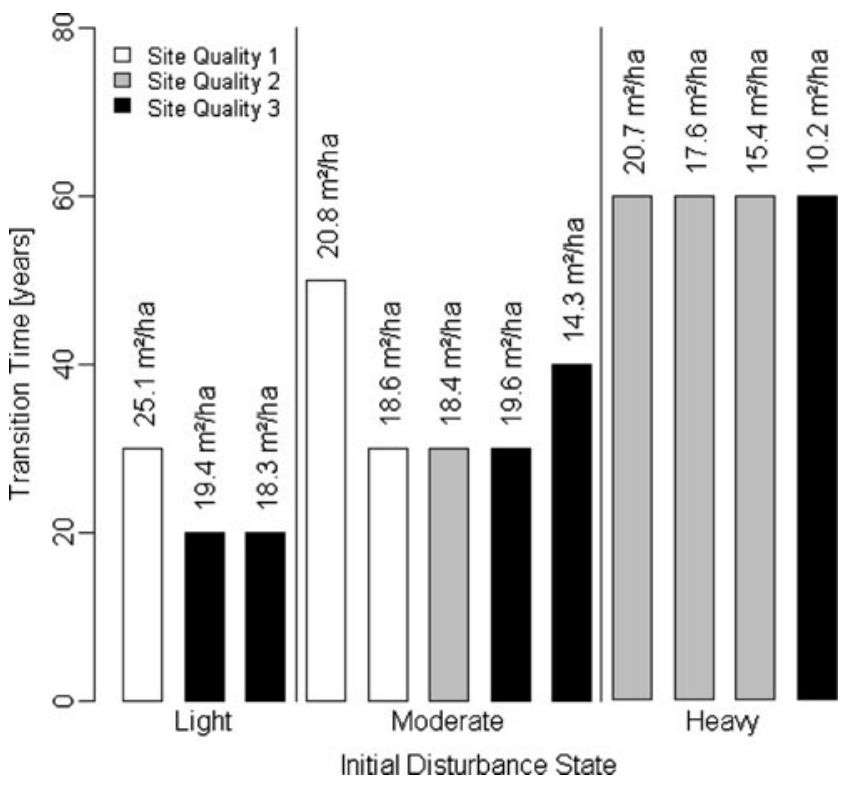

Fig. 4 Rounded transition times of disturbed stands toward a desired equilibrium by degree of disturbance at the beginning of the simulation and site quality. Above the bars are the initial stand basal areas

\subsubsection{Preliminary assessment of wildfire effects on long-term growth and yield}

Our simulation results show very clearly the effects of distinct regeneration deficiencies due to wildfires on longterm yield (Fig. 5). Expectedly, the higher the intensity and frequency of the wildfires, the lower the long-term yield whereby the frequency effect is considerably stronger than the intensity effect. However, interesting are the long-term dynamics. For the first 100 years, the difference between annual yields of the different wildfire frequencies was rather small because during this time span, the number of trees in large diameter classes was still high enough to maintain a more or less stable harvesting volume in each cycle. However, after 100 years, the lack of recruitment reached the large diameter classes. From that time on, the harvesting volumes in these stands differed significantly. Partly, after a local minimum, the harvesting volumes slightly increase again. This comes from the lower stand densities that result when the lack of recruitment arrives in the high diameter classes. With lower stand densities, recruitment numbers, although reduced by fires, increase again. That in turn leads to a slight recovery of the harvesting volumes on the long run. 
Fig. 5 Simulated effects of wildfires with different frequencies and intensities on long-term annual yield. a-d represent different intensities, where $100 \%, 75 \%, 50 \%$, and $25 \%$ of the current year's recruits die due to wildfires
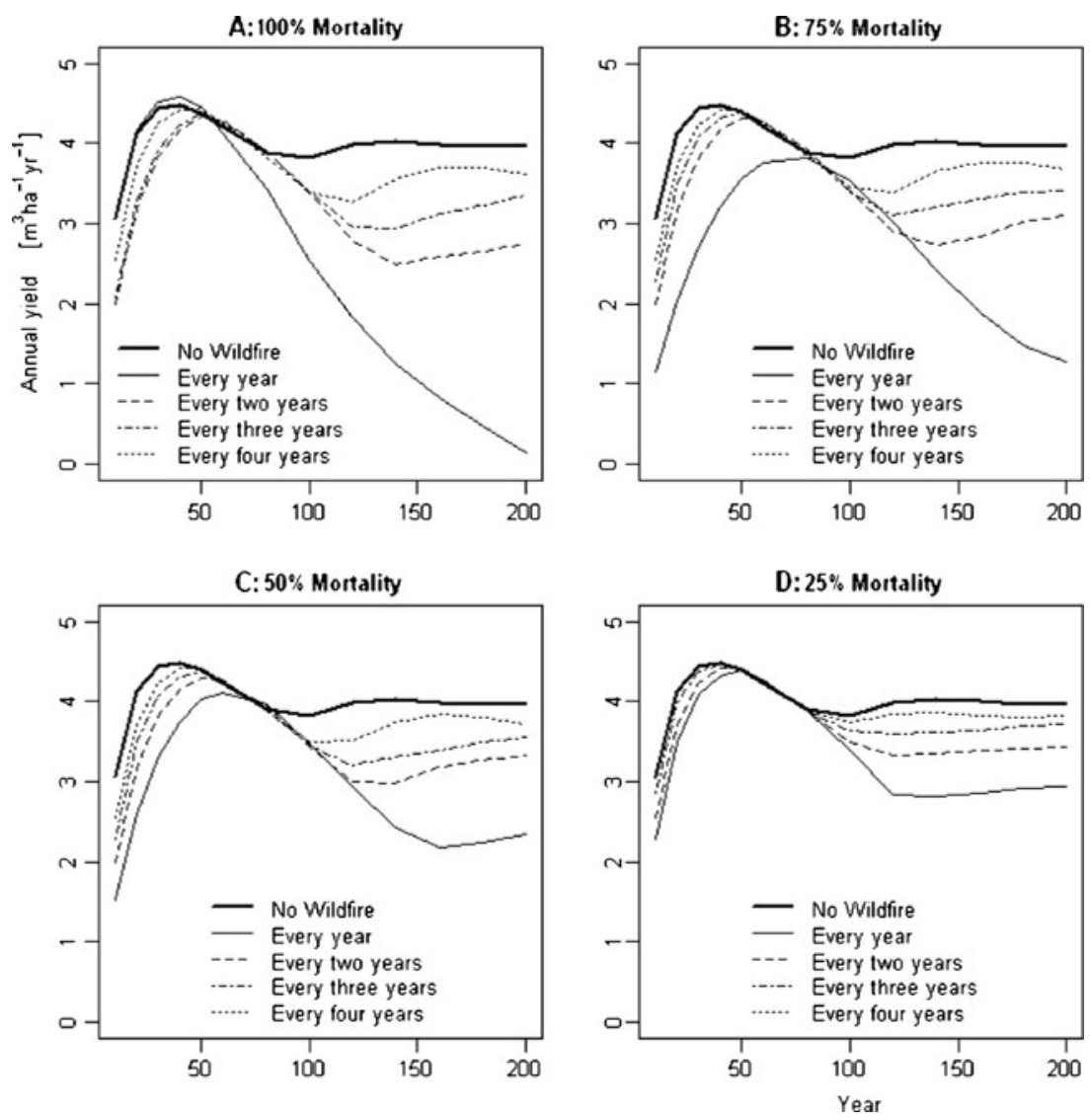

Clearly, the general decrease of harvesting volume was the highest in the case of wildfires occurring every year with no recruitment surviving a fire, this scenario leading into total stand destruction on the long run. However, all other runs, except the ones with annual wildfire occurrence stabilized at annual harvesting volumes between 3 and $4 \mathrm{~m}^{3} \mathrm{ha}^{-1}$ year $^{-1}$.

Compared to the scenario of no wildfire occurring, the annual yield decreased from $5 \%$ to $40 \%$ depending on fire frequency and intensity. However, the latter value was not obtained in an equilibrium and was only the average from the simulation time span. In addition, as our model assumptions concerning wildfire effects on recruitment are very simple, these results must be considered to be on the optimistic side.

\section{Discussion}

The chosen model approach with the subsequently discussed shortcomings with respect to empirical data base and limitations in its field of application is rather representative of countries like Vietnam. There, growth and yield data are scarce in general and even more limited with respect to complex forests. What are needed for sustainable management are simple tools and prescriptions for analyzing and managing such forests. Despite the availability of many highly sophisticated model approaches for other countries (Landsberg 2003; Pretzsch et al. 2008; Muys et al. 2010), model building in such cases must be adapted to the regional information base, information demand, and practicability. Thus, in the following, we discuss the lessons learned from this modeling exercise, restrictions of model application, and perspectives.

\subsection{Model development despite poor information basis}

As stated by Diep (1993), the dipterocarp forests in Vietnam have been overharvested for a long time in the past. The actual diameter distribution of the forests has been heavily disturbed and is not following the inverse J-shape typically found with uneven-aged forests. Currently, there are mainly young, poor, and degraded forests, just a few medium and rich stands. In order to avoid or at least slow down the replacement of these quite natural forests by forest plantations, models for predicting their productivity and developing silvicultural prescriptions like thinning rules, threshold diameter cutting, etc. are urgently required to ensure their sustainable management. However, the data base on growth and yield, methodological know-how of model building, and information technology have to be taken into due consideration in a modeling approach (Schütz 2001). 
The density-dependent size class model with steering options by the $q$ factor approach enables scenario calculations for analyzing the general dynamics of dipterocarp forests and allows long-term planning including optimization of stand productivity and derivation of respective target diameter distributions. The diameter distribution approach enables forest planners to provide the input data needed for the model and generates model output in the resolution required in practice. Simpler approaches would not sufficiently take forest structure into account, more complex approaches are likely to overburden practitioners with data acquisition and output interpretation. The technical implementation with the software VENSIM enables platform independent application for management and teaching.

The model was constructed based on the main components diameter increment, mortality, and recruitment associated with competition such as slowing down of tree growth and recruitment while increasing mortality when density increases. However, a limitation is that specific effects of competition release by harvest on mortality and recruitment could not be considered in the model because there exists no sufficient knowledge yet. For this reason, the model cannot be used to explore optimal harvesting cycles from the point of view of timber productivity. Therefore, the cycle should be chosen in accordance with the production practice. In this study, a short harvesting cycle of 10 years was applied because it is practical to the community forest management in Vietnam (Huy 2007).

The first steps for overcoming model shortcomings on the long run with respect to prediction of thinning reactions, regeneration, mortality, and recovery after fire have been made by establishment and first survey of long-term experiment plots with standardized measurement of all structural components in present and in defined intervals in future (Nguyen 2009). We consider the presented model a useful first version which, however, reveals lack of empirical data, necessity of information, and knowledge organization and draws attention on further research demand.

\subsection{Lesson learned for sustainable management of dipterocarp forests}

The $q$ factor approach (Weetman 2005) proved to be practical for quantifying and steering stand development. Following this concept, regulation of the forest state through cutting was carried out not only in the large but also in medium diameter classes. This means timber as well as fuelwood is removed and meets the current needs of local people and also serves to regulate the forest step by step toward desired structures. However, as the example of plot 8 shows, there are initial stand structures where restricting wood retrieval from the smaller diameter classes is necessary in order to obtain an equilibrium in the end. However, the model helps identifying situations where such restrictions are necessary and thus helps avoiding overall limitations which are hardly accepted by local people and difficult to enforce.

In many studies, the $q$ factor guide was applied for calculation of the financial return, timber productivity, or diversity index (e.g., Lu and Buongiorno 1993; Lin et al. 1998). In these studies, a diameter distribution of the stand was fixed by constant values of the $q$ factor, stand basal area, and the largest diameter class. In contrast, in this study, we applied the scenario analysis method and used the model to simulate various initial stand states under the method of $q$ factor guide. As there is a strong feedback relation between factors of the forest structure and the growth process (Biber and Weyerhaeuser 1999), the growth model proved to be an effective tool for analyzing the effect of a chosen equilibrium diameter distribution on stand yield. From the simulation results, the distributions that produced the highest sustainable yields were determined. According to Biber and Weyerhaeuser (1999), knowledge for sustainable forest management should always incorporate structural aspects.

Based on the simulation results, the following sitespecific equilibrium diameter distributions that give maximum yield were specified. For the most fertile sites, stand basal area $=20 \mathrm{~m}^{2} \mathrm{ha}^{-1}, q=1.4$, and maximum diameter= $70 \mathrm{~cm}$ for species groups 1 and 2 and $35 \mathrm{~cm}$ for species group 3 produced maximum yield. The corresponding parameters for the mediocre sites are stand basal area= $18 \mathrm{~m}^{2} \mathrm{ha}^{-1}, q=1.5$, and maximum diameter $=60 \mathrm{~cm}$ for species group 1 and 2 and $35 \mathrm{~cm}$ for species group 3 . The poor sites require a much lower density for maximizing yield: stand basal area $=16 \mathrm{~m}^{2} \mathrm{ha}^{-1}, q=1.6$, and maximum diameter $=50 \mathrm{~cm}$ for species group 1 and 2 and $35 \mathrm{~cm}$ for species group 3 .

Equilibrium distributions explored by the model can serve as a good guideline for the production practice of the dipterocarp forests in Vietnam. The simulations revealed that the required time of transformation from present to desired diameter distributions tended to correlate with the initial stand basal area. Stands with high basal area usually had lower transformation times than those with low basal area. For example, for plot 3 with a high basal area of $25 \mathrm{~m}^{2} / \mathrm{ha}$, it took only 30 years to reach the target state while for plot 8 with a very low basal area, it took 60 years. However, the transformation time depended not only on the stand basal area but also on the initial distribution. Typical examples are plot 2 and plot 12 . They had similar initial stand basal areas but very different distribution states (cf. Fig. 11 in the "Appendix," available at www.afs-journal.org). Plot 12 had an initial distribution very close to the target distribution. Therefore, it took only about 20 years to reach the desired equilibrium distribution, just after two cuttings. Plot 2 
had a quite high basal area of $20.7 \mathrm{~m}^{2} \mathrm{ha}^{-1}$. However, its initial distribution was very far from the target one. Therefore, it took about 60 years to regulate this stand toward the target state.

So far, the Vietnamese Government's policy for allocating forests to local people only relies on stand basal area for defining what silvicultural measures are allowed. In poor forests (basal area $<10 \mathrm{~m}^{2} / \mathrm{ha}$ ), harvesting is forbidden. The goal is to enrich these forests by promoting natural regeneration. In average and rich forests (basal area $>10 \mathrm{~m}^{2} / \mathrm{ha}$ ), harvest is allowed in the frame of certain technical prescriptions. The results of this study suggest that our model could help to optimize stand treatment and the local people's timber and firewood supply by developing guidelines that take into account not only basal area but also the diameter distribution.

In all scenarios with wildfires occurring in longer than 1 -year time intervals, the forests seem to come into equilibrium. The level of this equilibrium was dependent on fire frequency and intensity, whereas intensity impacts the annual yield more than the frequency. Remarkably, over the whole range of intensities, quadrennial fire occurrences lead to almost the same equilibrium yield as it results from the no-fire scenario. Total stand destruction only appeared with annual fire occurrence and $0 \%$ or $25 \%$ recruit survival rate, not with the most typical scenarios of biennial wildfires combined with survival rates of $25-50 \%$ per occurrence.

\subsection{Further improvement of the prediction of fire effects on stand dynamics}

The majority of the dipterocarp forests in Vietnam are heavily disturbed by natural factors, especially by wildfires. But hardly any information on frequency of fires, effects on different tree species in the upper layer, and regeneration and on time of recovery of regeneration and understoried trees after fire is available. Even so, a first conceptual approach for modeling and assessment of fire effects was realized. The effects of wildfires on stand diameter distribution and growth were implemented in the model assuming various decreasing levels of recruitment when wildfire occurred. The simulation results showed that wildfires greatly reduced the long-term yield and disturbed stand structure.

In our simulations, wildfires caused the forests to be heavily disturbed, and hence, the target diameter distribution could not be reached. When evaluating the impacts of wildfire on the long-term yield of the dipterocarp forests, the simulations were based on assumptions of different intensities and frequencies of wildfire occurrence. These assumed wildfire intensities and frequencies were in the range likely to exist in practice. Compared with the case of no wildfire occurring, the long-term annual yield decreased from $5 \%$ in the case with wildfires occurring every 4 years and the lowest intensity to $40 \%$ in the case with wildfire occurring every year and the highest intensity.

However, the more important issue was that when wildfires frequently occurred, the structure of forest was heavily disturbed over time because it led to reduction in the number of recruits, so that the regulation process of the stand toward the target distribution could not be obtained. The results supported the special role of the regeneration process to the forest structure stability specified by Diep (1993). Compared to the target distribution, there was always a lack of trees in the small diameter classes. Particularly, in the case of wildfires occurring every year, under the application of the harvesting rule, large trees with a given diameter were cut while no new trees came from recruitment. The growing stock of the stand gradually declined. Therefore, after approximately 150 years, this stand would be nearly devastated.

The system of permanent plots established recently for this work in the dipterocarp forests included a first inventory of regeneration and understoried trees (Nguyen 2009). Subsequent surveys in 3-year steps will provide the necessary data for validation of the regeneration module, the calibration, and further development of this crucial model element. Specifically, this kind of data will allow us to estimate the time spans recruits need for growing into the main stand. Thus, we will be able to extend our model for covering the effect that recruitment may suffer from fire damage for several years after fire occurrence.

\section{Conclusions}

Old and secondary growth forests could provide a broad range of forest goods and services, but information and planning tools for their sustainable management are missing so far mainly due to their complexity (Puettmann et al. 2009). So, they are frequently replaced, in the case of dipterocarp forests in Vietnam, by agricultural land or plantations, as the latter seem more productive, easier to manage and to model. This growing preference of forest management on monocultures leads to a further lack of experiments, data, models, and silvicultural prescriptions for more natural and heterogeneous stands. However, forest practice can hardly be convinced to evolve toward more natural ecosystems as long as sound information about growth and yield of the objective is missing. This dilemma is well-known in Europe where the monoculture yield tables were first praised as the main achievements of forest science and later criticized as the major obstacle on the way to close-to-nature forest (Pretzsch 2009). 
Insofar, the conceptual modeling framework and applications presented in this study have a pilot character for opening alternatives to the common transformation of natural stands into plantations.

By choosing a top-down model approach which relies on general rules of stand dynamics, it strives to make the best out of a rather restricted existing database. The approach needs further development but already provides valuable insights into the performance of the endangered dipterocarp forests, approaches how to use and sustain them and keep them practically in the play as an alternative to artificial forests.

Acknowledgments The research reported in this paper was supported by a scholarship of the Project 322, Ministry of Education and Training of Vietnam. Additional funding was provided by Deutscher Akademischer Austauschdienst. The authors would like to thank the branch of Forest Inventory and Planning Institute of Vietnam in Central Highlands for generously providing valuable data from permanent plots of dipterocarp forests. Thanks are also to Dr. Phan Hoang Dong, Research Institute for Forest Ecology and Forestry Rhineland-Palatinate, Trippstadt, Germany for helpful contributions and two anonymous reviewers for valuable comments.

\section{Appendix}

Fig. 6 Simulated basal area evolutions of an undisturbed stand over 1,000 years with three site qualities
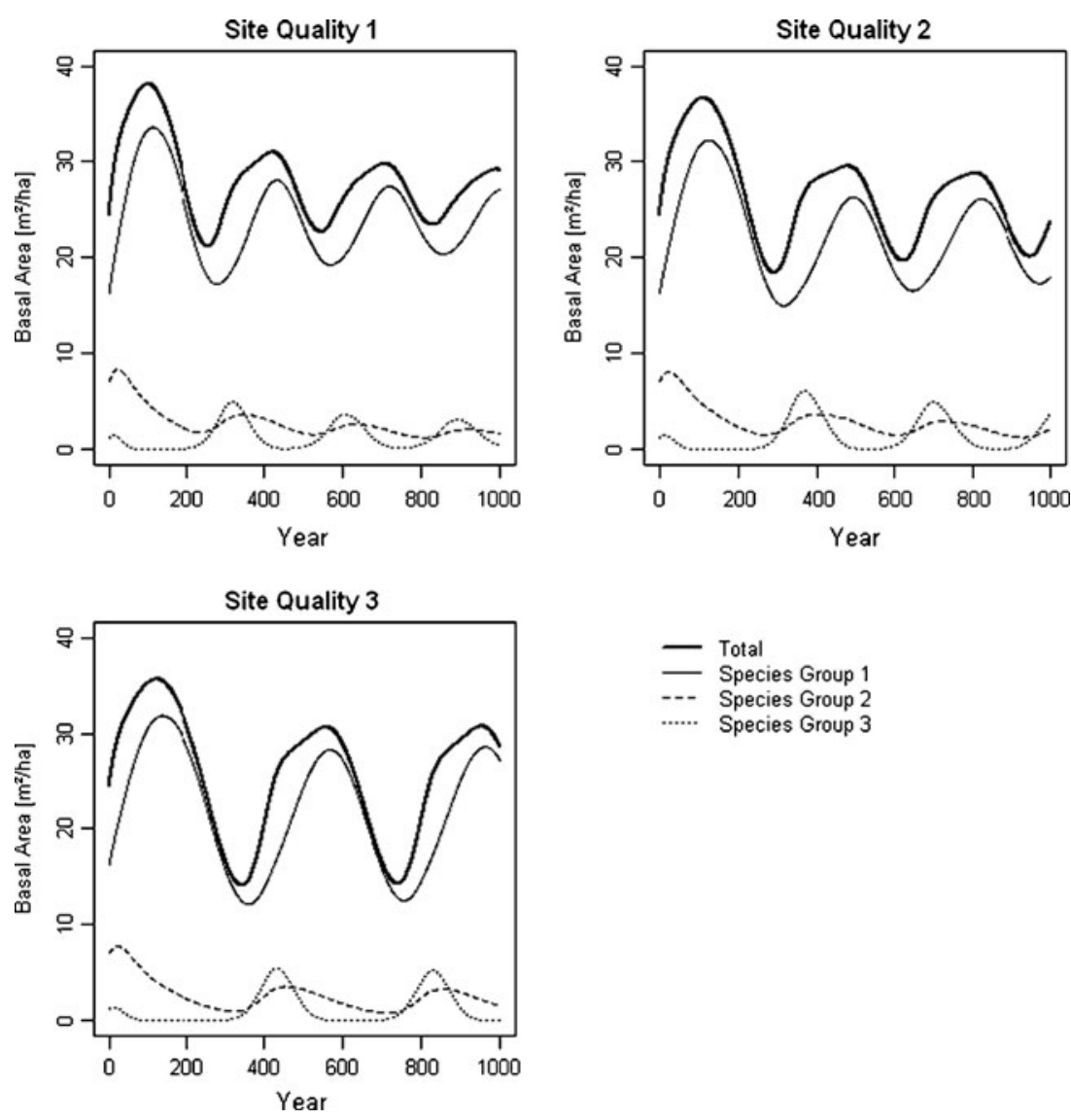

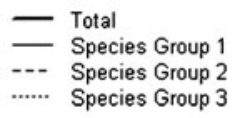


Fig. 7 Predicted long-term diameter distribution evolutions of an undisturbed stand with site quality 1 . Note that the largest diameter class contains all trees with a diameter $\geq 81 \mathrm{~cm}$
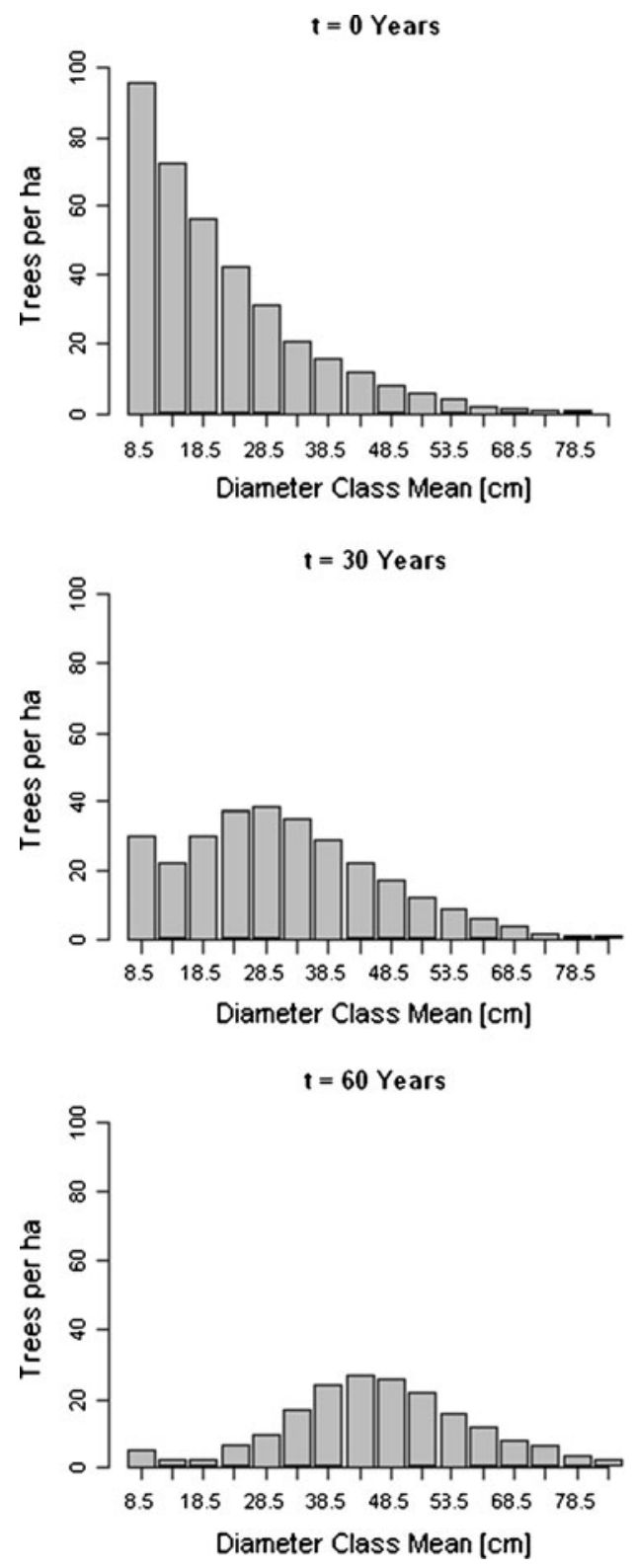

$t=250$ Years
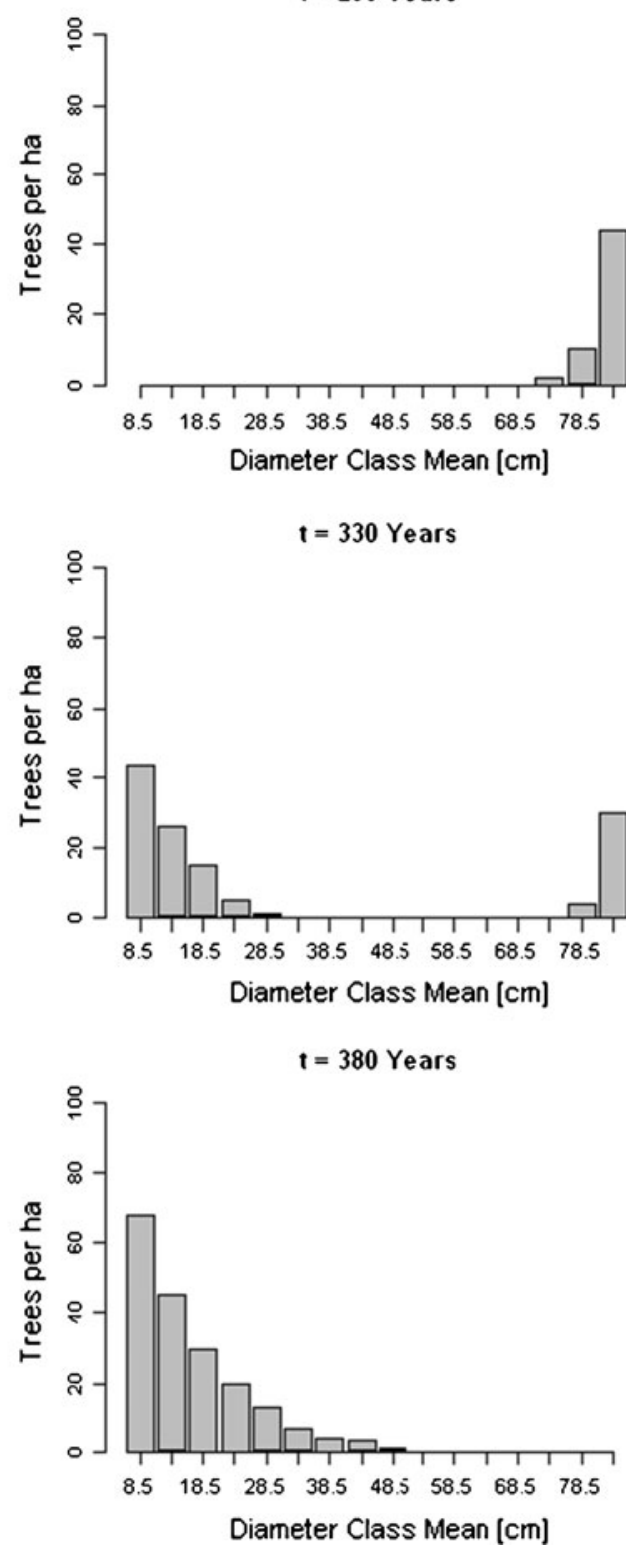
Fig. 8 The target diameter distributions (5-cm classes) found to produce the maximum sustainable yield for the three species groups by the three site qualities
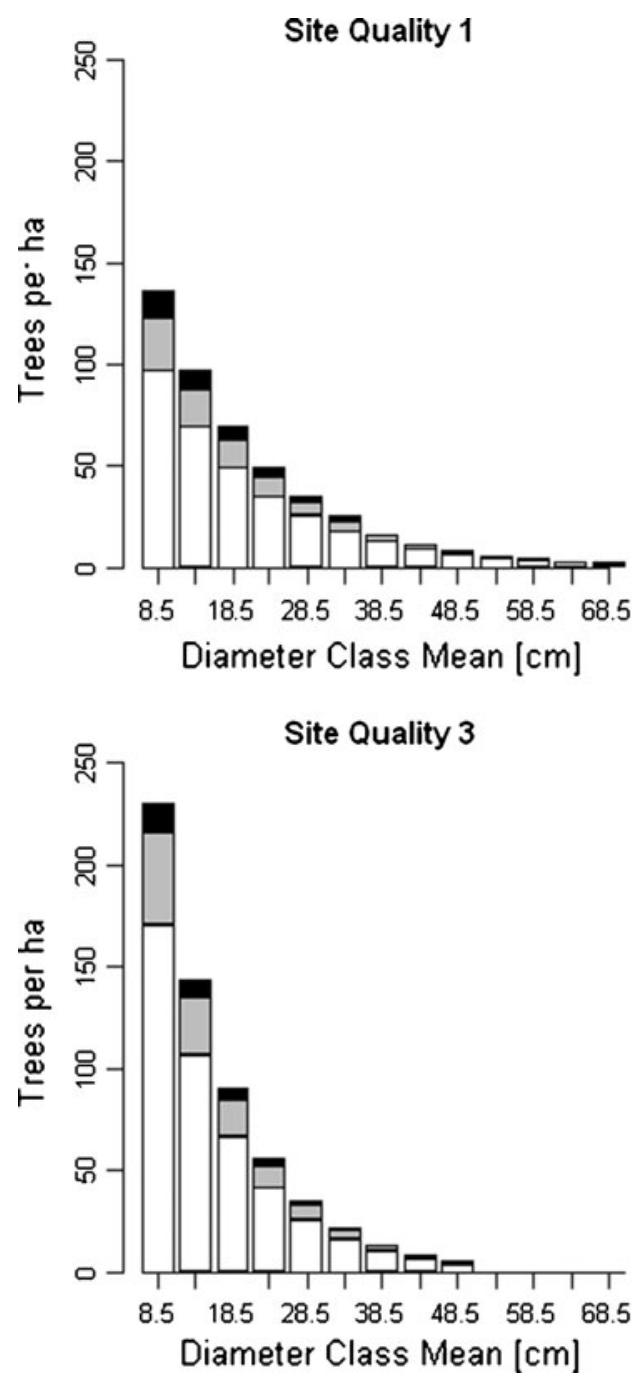

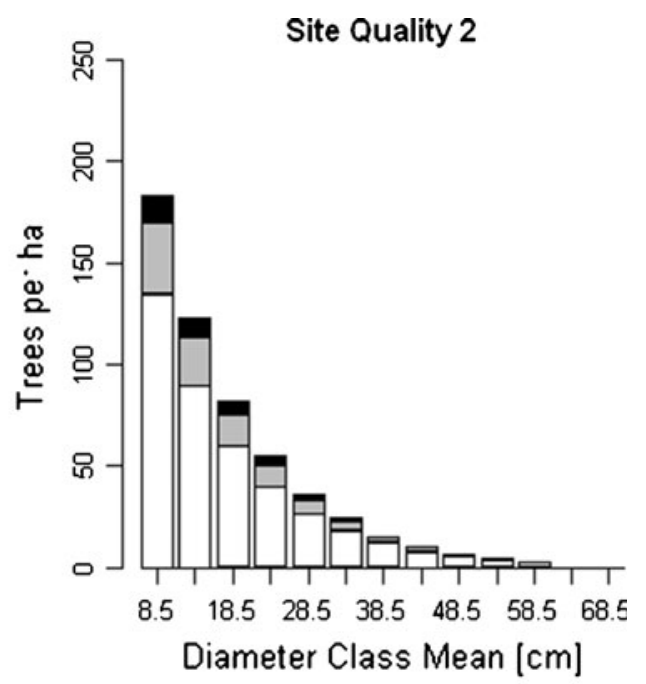

$\square$ Species Group 1

$\square$ Species Group 2

- Species Group 3

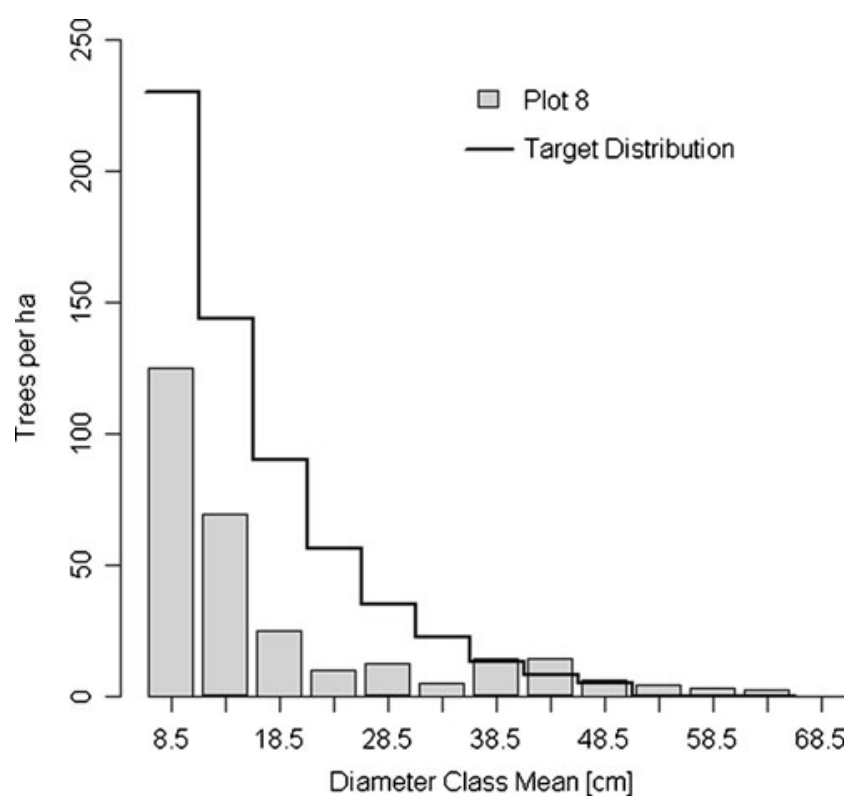

Fig. 9 Diameter distribution of the heavily disturbed plot 8 at the first measurement vs. target distribution 
Fig. 10 Simulated

transformation of an overharvested stand (by example of plot 8) toward a sustainable target state. a Stand basal area, $\mathbf{b}$ stand volume, $\mathbf{c}$ harvested volume, $\mathbf{d}$ target diameter distribution and simulated distributions in 20year intervals
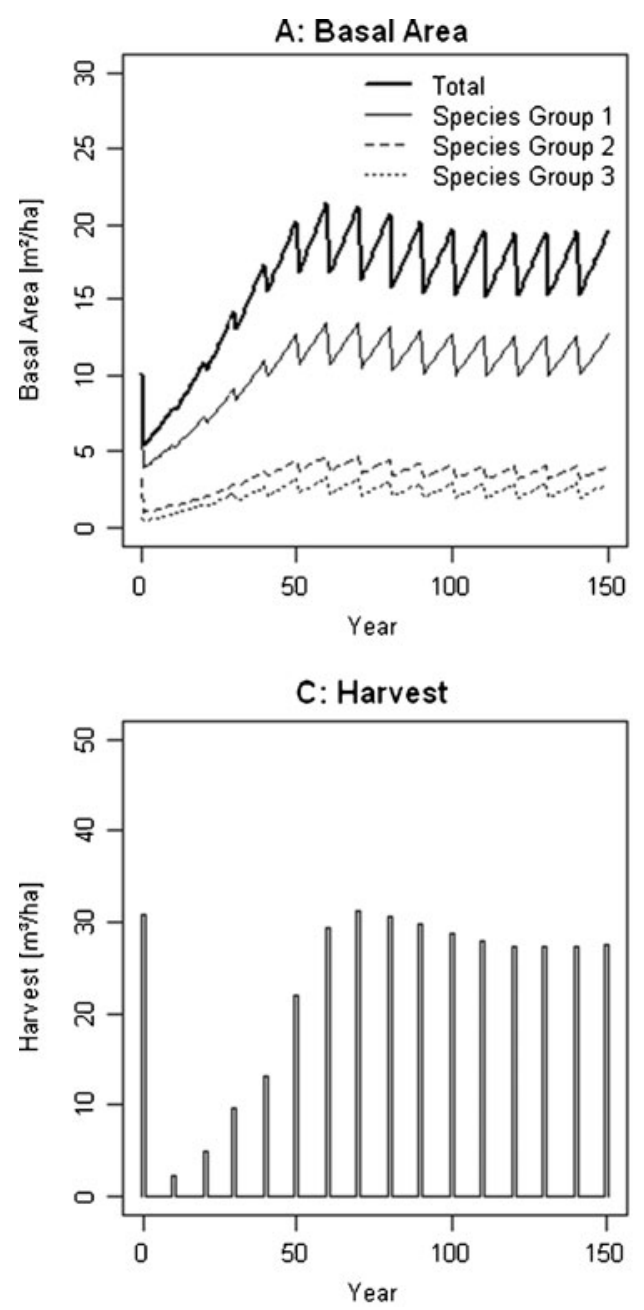

B: Volume
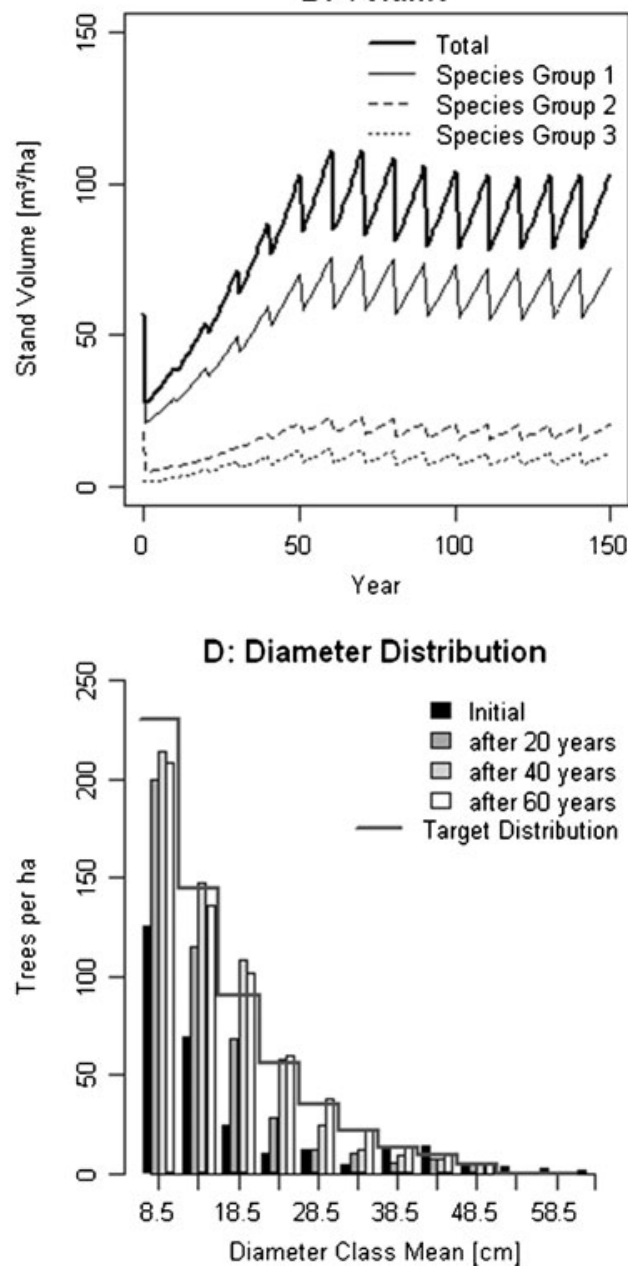

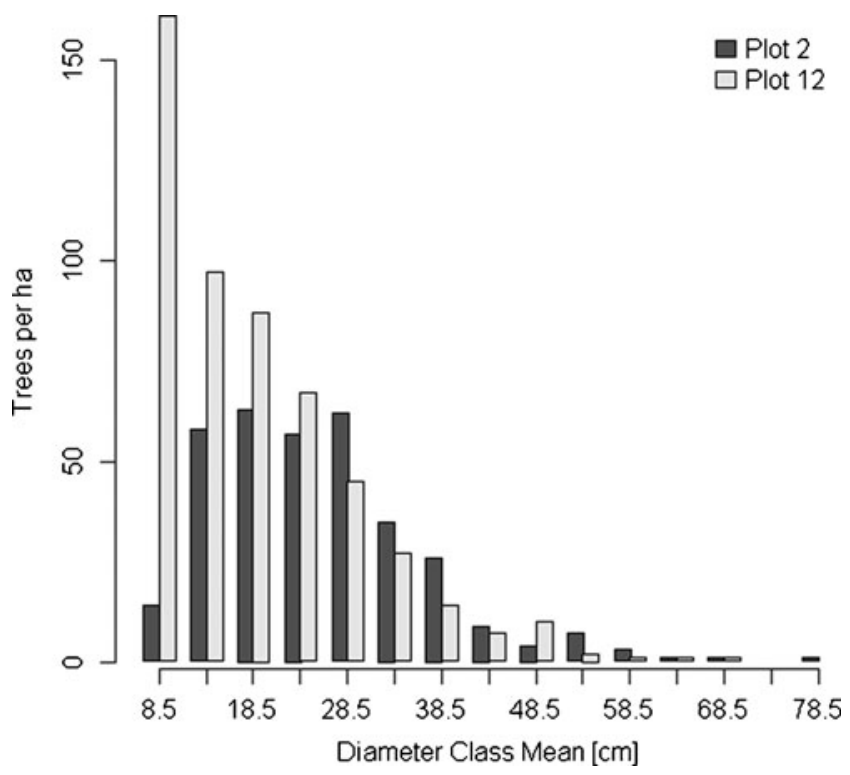

Fig. 11 Typical diameter distribution of a nearly undisturbed (plot 12) and a heavily disturbed plot (plot 2) 
Table 5 Complete list of tree species in the research plots in the Yok Don National Park

\begin{tabular}{|c|c|c|c|}
\hline No & Scientific name & Family & Species group \\
\hline 1 & Styrax benzoin & Styracaceae & 3 \\
\hline 2 & Lagerstroemia calyculata & Lythraceae & 1 \\
\hline 3 & Vitex sumatrana & Verbenaceae & 2 \\
\hline 4 & Litsea lancilimba & Lauraceae & 2 \\
\hline 5 & Ceiba pentandra & Bombaceae & 2 \\
\hline 6 & Grcinia oblongifolia & Glusiaceae & 3 \\
\hline 7 & Masstixia arborea & Cornaceae & 3 \\
\hline 8 & Shorea obtusa & Dipterocarpaceae & 1 \\
\hline 9 & Parinari annamensis & Chrysobalanaceae & 2 \\
\hline 10 & Dalbergia mamosa & Fabaceae & 2 \\
\hline 11 & Shorea siamensis & Dipterocarpaceae & 1 \\
\hline 12 & Xylia dolabriformis & Mimosaceae & 2 \\
\hline 13 & Engelhardtia spicata & Juglandaceae & 3 \\
\hline 14 & Terminalia alata & Combretaceae & 1 \\
\hline 15 & Terminalia bellirica & Combretaceae & 2 \\
\hline 16 & Antidesma ghaesembilla & Euphorbiaceae & 2 \\
\hline 17 & Combretum trifoliatum & Combretaceae & 2 \\
\hline 18 & Microcos paniculata & Tiliceae & 2 \\
\hline 19 & Lumnitzera coccinea & Anacardiaceae & 3 \\
\hline 20 & Pterocarpus pedatus & Fabaceae & 2 \\
\hline 21 & Dipterocarpus tuberculatus & Dipterocarpaceae & 1 \\
\hline 22 & Dipterocarpus obtusifolius & Dipterocarpaceae & 1 \\
\hline 23 & Syndiclis lotungensis & Lauraceae & 2 \\
\hline 24 & Vitex quinata & Verbenaceae & 2 \\
\hline 25 & Randia spinosa & Rubiaceae & 2 \\
\hline 26 & Bombax anceps & Bombaceae & 2 \\
\hline 27 & Adina cordifolia & Rubiaceae & 2 \\
\hline 28 & Lithocarpus ducampii & Fagaceae & 2 \\
\hline 29 & Ceiba pentandra & Bombaceae & 2 \\
\hline 30 & Sindora siamensis & Caesalpiniaceae & 2 \\
\hline 31 & Paulownia fortunei & Scrophulariaceae & 2 \\
\hline 32 & Rhodoleia champion & Hamamelidaceae & 3 \\
\hline 33 & Aesculus chinensis & Hippocastanaceae & 2 \\
\hline 34 & Phoebe cuneata & Lauraceae & 3 \\
\hline 35 & Hopea pierrei & Dipterocarpaceae & 1 \\
\hline 36 & Grewia afpaniculata & Tiliaceae & 2 \\
\hline 37 & Irvigia malayana & Irvigiaceae & 2 \\
\hline 38 & Peltophorum tonkinensis & Caesalpiniaceae & 2 \\
\hline 39 & Barringtonia acutagula & Lecythidaceae & 2 \\
\hline 40 & Pterospermum diversifolium & Sterculiaceae & 2 \\
\hline 41 & Strychnos nuxblanda & Loganiaceae & 3 \\
\hline 42 & Phyllanthus emblica & Euphorbiaceae & 3 \\
\hline 43 & Bauhinia purpurea & Caesalpiniaceae & 3 \\
\hline 44 & Cassia siamea & Fabaceae & 2 \\
\hline 45 & Morinda citrifolia & Rubiaceae & 3 \\
\hline 46 & Diospyros pilosella & Ebenaceae & 3 \\
\hline 47 & Oroxylum indicum & Bignoniaceae & 3 \\
\hline 48 & Stereospermum cylindricum & Bignoniaceae & 3 \\
\hline
\end{tabular}

Table 5 (continued)

\begin{tabular}{llll}
\hline No & Scientific name & Family & Species group \\
\hline 49 & Butea frondosa & Legumimoseae & 3 \\
50 & Hopea odorata & Dipterocarpaceae & 1 \\
51 & Shorea roxburghii & Dipterocarpaceae & 1 \\
52 & Hopea recopei & Dipterocarpaceae & 1 \\
53 & Rhus succedanea & Anacardiaceae & 2 \\
54 & Ziziphus oenoplia & Rhamnaceae & 3 \\
55 & Vatica odorata & Dipterocarpaceae & 1 \\
56 & Cratoxylon sp. & Clusiaceae & 3 \\
57 & Aporosa sp & Euphorbiaceae & 3 \\
58 & Diospyros sp. & Ebenaceae & 3 \\
59 & Wrightia tomentosa & Apocynaceae & 3 \\
60 & Canarium album & Burseraceae & 2 \\
61 & Syzygium cuminii & Myrtaceae & 2 \\
62 & Anisoptera costata & Dipterocarpaceae & 1 \\
63 & Careya sphaerica & Lecythidaceae & 2 \\
64 & Mangifera longipetiolata & Meliaceae & 2 \\
\hline
\end{tabular}

For each species, the group affiliation used in this work is shown
Table 6 Parameters of the diameter-height relationship from Eq. 10

\begin{tabular}{llll}
\hline Species group & Site quality & $a$ & $b$ \\
\hline 1 & 1 & 0.3266 & 1.9281 \\
& 2 & 0.3441 & 1.7069 \\
& 3 & 0.3617 & 1.8762 \\
2 & 1 & 0.3544 & 1.7413 \\
& 2 & 0.3653 & 1.8291 \\
& 3 & 0.3831 & 1.6328 \\
3 & 1 & 0.4099 & 1.1985 \\
& 2 & 0.4025 & 1.4807 \\
& 3 & 0.3959 & 1.8935 \\
\hline
\end{tabular}


Table 7 Predicted vs. observed basal areas for each plot for the three species groups, after five simulation years

\begin{tabular}{|c|c|c|c|c|c|}
\hline \multirow[t]{2}{*}{ Plot } & \multirow{2}{*}{$\begin{array}{l}\text { Species } \\
\text { group }\end{array}$} & \multirow[t]{2}{*}{ BA $1\left(\mathrm{~m}^{2} \mathrm{ha}^{-1}\right)$} & \multicolumn{2}{|c|}{ BA $2\left(\mathrm{~m}^{2} \mathrm{ha}^{-1}\right)$} & \multirow{2}{*}{$\begin{array}{l}\text { Difference } \\
\text { percentage }\end{array}$} \\
\hline & & & Observed & Predicted & \\
\hline \multirow[t]{4}{*}{1} & 1 & 13.07 & 14.96 & 14.70 & \\
\hline & 2 & 4.40 & 4.75 & 4.80 & \\
\hline & 3 & 0.87 & 1.02 & 1.00 & \\
\hline & Total & 18.34 & 20.73 & 20.52 & -1.01 \\
\hline \multirow[t]{4}{*}{2} & 1 & 16.09 & 18.14 & 17.98 & \\
\hline & 2 & 4.07 & 4.37 & 4.47 & \\
\hline & 3 & 0.57 & 0.64 & 0.65 & \\
\hline & Total & 20.74 & 23.15 & 23.09 & -0.26 \\
\hline \multirow[t]{4}{*}{3} & 1 & 17.37 & 18.70 & 18.68 & \\
\hline & 2 & 6.56 & 7.01 & 7.00 & \\
\hline & 3 & 1.10 & 1.19 & 1.20 & \\
\hline & Total & 25.04 & 26.90 & 26.88 & -0.07 \\
\hline \multirow[t]{4}{*}{4} & 1 & 16.31 & 17.89 & 17.70 & \\
\hline & 2 & 3.97 & 4.13 & 4.20 & \\
\hline & 3 & 0.48 & 0.63 & 0.60 & \\
\hline & Total & 20.77 & 22.66 & 22.60 & -0.26 \\
\hline \multirow[t]{4}{*}{5} & 1 & 15.72 & 17.55 & 17.40 & \\
\hline & 2 & 3.35 & 3.61 & 3.56 & \\
\hline & 3 & 0.56 & 0.63 & 0.64 & \\
\hline & Total & 19.62 & 21.79 & 21.60 & -0.87 \\
\hline \multirow[t]{4}{*}{6} & 1 & 14.19 & 15.85 & 16.22 & \\
\hline & 2 & 3.69 & 4.14 & 4.17 & \\
\hline & 3 & 0.749 & 0.85 & 0.87 & \\
\hline & Total & 18.62 & 20.84 & 21.26 & 2.02 \\
\hline \multirow[t]{4}{*}{7} & 1 & 15.06 & 17.49 & 17.12 & \\
\hline & 2 & 3.98 & 4.28 & 4.20 & \\
\hline & 3 & 0.32 & 0.36 & 0.40 & \\
\hline & Total & 19.35 & 22.14 & 21.72 & -1.90 \\
\hline \multirow[t]{4}{*}{8} & 1 & 6.32 & 7.30 & 7.14 & \\
\hline & 2 & 3.22 & 3.46 & 3.53 & \\
\hline & 3 & 0.60 & 0.72 & 0.78 & \\
\hline & Total & 10.15 & 11.48 & 11.44 & -0.35 \\
\hline \multirow[t]{4}{*}{9} & 1 & 8.97 & 10.23 & 10.09 & \\
\hline & 2 & 4.77 & 5.15 & 5.18 & \\
\hline & 3 & 0.60 & 0.650 & 0.75 & \\
\hline & Total & 14.34 & 16.04 & 16.03 & -0.06 \\
\hline \multirow[t]{4}{*}{10} & 1 & 12.38 & 13.91 & 13.69 & \\
\hline & 2 & 4.54 & 4.91 & 5.01 & \\
\hline & 3 & 0.66 & 0.73 & 0.72 & \\
\hline & Total & 17.60 & 19.56 & 19.42 & -0.72 \\
\hline \multirow[t]{4}{*}{11} & 1 & 9.06 & 10.35 & 10.18 & \\
\hline & 2 & 5.49 & 5.95 & 6.02 & \\
\hline & 3 & 0.80 & 0.85 & 0.93 & \\
\hline & Total & 15.36 & 17.15 & 17.13 & -0.12 \\
\hline \multirow[t]{4}{*}{12} & 1 & 15.55 & 17.86 & 17.56 & \\
\hline & 2 & 2.17 & 2.43 & 2.39 & \\
\hline & 3 & 0.53 & 0.63 & 0.63 & \\
\hline & Total & 18.26 & 20.92 & 20.58 & -1.63 \\
\hline
\end{tabular}

Difference percentage $=\left(\right.$ BA $\left.2_{\text {observed }}-\mathrm{BA} 2_{\text {predicted }}\right) / \mathrm{BA} 2_{\text {observed }} \times 100 \%$ $B A 1$ basal area at the first measurement, $B A 2$ basal area at the second measurement
Table 8 Predicted vs. observed average number of trees per hectare for each site quality by 5 -cm-diameter classes for the 12 plots after a 5 year simulation interval

Diameter class mean (cm) Tree number by diameter class (trees $\mathrm{ha}^{-1}$ )

Site quality Site quality Site quality 3 12

Pred. Obs. Pred. Obs. Pred. Obs.

Species group 1

$\begin{array}{lrlrrrl}8.5 & 29.8 & 38.8 & 38.7 & 38.8 & 115.3 & 128.6 \\ 13.5 & 31.8 & 35 & 33.3 & 34.8 & 68.5 & 68.2 \\ 18.5 & 37.8 & 37.3 & 33.1 & 34.8 & 47.7 & 51.6 \\ 23.5 & 25.8 & 23.7 & 25.9 & 24.5 & 41.3 & 42 \\ 28.5 & 16.3 & 16.0 & 27.0 & 27.0 & 28.9 & 29.6 \\ 33.5 & 17.2 & 16.7 & 22.7 & 23.3 & 17.2 & 16.8 \\ 38.5 & 13.4 & 14.1 & 14.1 & 14.0 & 12.1 & 12.8 \\ 43.5 & 10.8 & 10.3 & 11.1 & 12.3 & 9.3 & 10.1 \\ 48.5 & 8.3 & 9.7 & 7.7 & 8.0 & 5.1 & 4.2 \\ 53.5 & 7.8 & 7.3 & 4.2 & 3.8 & 3.2 & 3.4 \\ 58.5 & 3.8 & 3.7 & 3.6 & 3.5 & 2.3 & 2.2 \\ 61+ & 11.4 & 11.3 & 3.2 & 3.3 & 2.3 & 2.4\end{array}$

Species group 2

$\begin{array}{llllll}16.0 & 14.0 & 16.8 & 16.3 & 17.9 & 19.8\end{array}$

$\begin{array}{llllll}12.8 & 13.7 & 14.8 & 15 & 13.5 & 15.2\end{array}$

$\begin{array}{llllll}14.5 & 15.3 & 11.1 & 11.5 & 8.8 & 8.6\end{array}$

$\begin{array}{llllll}13.0 & 13.3 & 9.3 & 9.0 & 5.4 & 5.0\end{array}$

$\begin{array}{llllll}6.3 & 5.3 & 7.2 & 7.8 & 4.7 & 4.8\end{array}$

$\begin{array}{llllll}6.8 & 7.3 & 5.8 & 5.8 & 3.6 & 3.4\end{array}$

$\begin{array}{llllll}3.1 & 3.0 & 6.2 & 5.5 & 3.1 & 3.2\end{array}$

$\begin{array}{llllll}2.6 & 2.7 & 3.5 & 3.5 & 2.2 & 2.0\end{array}$

$\begin{array}{llllll}1.4 & 1.1 & 1.7 & 2.3 & 2.3 & 2.4\end{array}$

$\begin{array}{llllll}1.9 & 2.0 & 1.9 & 2.0 & 1.3 & 1.6\end{array}$

$\begin{array}{llllll}1.5 & 1.7 & 1.1 & 0.8 & 1.0 & 0.8\end{array}$

$\begin{array}{llllll}2.7 & 2.7 & 2.0 & 1.8 & 1.6 & 1.6\end{array}$

Species group 3

8.5

$\begin{array}{llllll}16.3 & 18 & 9.1 & 13 & 10.3 & 11.2\end{array}$

13.5

$\begin{array}{llllll}9.9 & 11.3 & 6.3 & 6.3 & 11.6 & 9.6\end{array}$

$\begin{array}{llllll}6.1 & 4.0 & 2.9 & 2.5 & 4.8 & 4.4\end{array}$

$\begin{array}{llllll}4.7 & 5.1 & 3.4 & 3.3 & 3.0 & 2.8\end{array}$

$\begin{array}{llllll}2.3 & 2.3 & 1.3 & 1.0 & 1.1 & 0.8\end{array}$

$\begin{array}{llllll}0.8 & 1.0 & 0.5 & 0.3 & 0.3 & 0.4\end{array}$

$\begin{array}{llllll}0.1 & 0.1 & 0.5 & 0.5 & 0.2 & 0.2\end{array}$

$\begin{array}{llllll}0.5 & 0.3 & 0.3 & 0.5 & 0.1 & 0.1\end{array}$

43.5

$\begin{array}{llllll}0.1 & 0.3 & 0.4 & 0.2 & 0.1 & 0\end{array}$

$\begin{array}{lllllll}53.5 & 0 & 0 & 0.4 & 0.5 & 0.1 & 0.2\end{array}$

$\begin{array}{lllllll}58.5 & 0 & 0 & 0.2 & 0 & 0 & 0\end{array}$

$\begin{array}{lllllll}61+ & 0 & 0 & 0.1 & 0.2 & 0 & 0\end{array}$

Pred. Predicted, Obs. observed 
Table 9 Optimum equilibrium diameter distributions for the three site quality levels as found with scenario runs

\begin{tabular}{|c|c|c|c|c|c|c|c|c|c|c|c|c|}
\hline \multirow{3}{*}{$D$} & \multicolumn{4}{|c|}{ Site quality 1} & \multicolumn{4}{|c|}{ Site quality 2} & \multicolumn{4}{|c|}{ Site quality 3} \\
\hline & \multicolumn{4}{|c|}{$\mathrm{BA}=20 \mathrm{~m}^{2} \mathrm{ha}^{-1}, q=1.4$} & \multicolumn{4}{|c|}{$\mathrm{BA}=18 \mathrm{~m}^{2} \mathrm{ha}^{-1}, q=1.5$} & \multicolumn{4}{|c|}{$\mathrm{BA}=16 \mathrm{~m}^{2} \mathrm{ha}^{-1}, q=1.6$} \\
\hline & N 1 & $\mathrm{~N} 2$ & N 3 & $\mathrm{~N}$ total & N 1 & N 2 & N 3 & $\mathrm{~N}$ total & N 1 & N 2 & N 3 & $\mathrm{~N}$ tota \\
\hline 8.5 & 96.9 & 25.8 & 12.8 & 135.5 & 134.0 & 35.7 & 14.0 & 183.8 & 170.1 & 45.4 & 14.9 & 230.3 \\
\hline 13.5 & 69.2 & 18.5 & 9.1 & 96.8 & 89.3 & 23.8 & 9.3 & 122.5 & 106.3 & 28.3 & 9.3 & 143.9 \\
\hline 18.5 & 49.4 & 13.2 & 6.5 & 69.1 & 59.5 & 15.9 & 6.2 & 81.6 & 66.4 & 17.7 & 5.8 & 89.9 \\
\hline 23.5 & 35.3 & 9.4 & 4.6 & 49.3 & 39.7 & 10.6 & 4.2 & 54.4 & 41.5 & 11.1 & 3.6 & 56.2 \\
\hline 28.5 & 25.2 & 6.7 & 3.3 & 35.2 & 26.4 & 7.1 & 2.8 & 36.3 & 25.9 & 6.9 & 2.3 & 35.1 \\
\hline 33.5 & 18.0 & 4.8 & 2.4 & 25.2 & 17.6 & 4.7 & 1.8 & 24.2 & 16.2 & 4.3 & 1.4 & 21.9 \\
\hline 38.5 & 12.9 & 3.4 & & 16.3 & 11.7 & 3.1 & & 14.9 & 10.1 & 2.7 & & 12.8 \\
\hline 43.5 & 9.2 & 2.4 & & 11.6 & 7.8 & 2.1 & & 9.9 & 6.3 & 1.7 & & 8.0 \\
\hline 48.5 & 6.6 & 1.7 & & 8.3 & 5.2 & 1.4 & & 6.6 & 4.0 & 1.1 & & 5.0 \\
\hline 53.5 & 4.7 & 1.2 & & 5.9 & 3.5 & 0.9 & & 4.4 & & & & \\
\hline 58.5 & 3.3 & 0.9 & & 4.2 & 2.3 & 0.6 & & 2.9 & & & & \\
\hline 63.5 & 2.4 & 0.6 & & 3.0 & & & & & & & & \\
\hline 68.5 & 1.7 & 0.5 & & 2.2 & & & & & & & & \\
\hline $\mathrm{N}$ & 334.8 & 89.1 & 38.7 & 462.6 & 397 & 105.9 & 38.3 & 541.5 & 446.8 & 119.2 & 37.3 & 603.1 \\
\hline BA & 15.0 & 4.0 & 1.0 & 20.0 & 13.5 & 3.6 & 0.9 & 18.0 & 12.0 & 3.2 & 0.8 & 16.0 \\
\hline
\end{tabular}

$N 1$ tree number per hectare for the species group 1, N 2 tree number per hectare for the species group 2, $N 3$ tree number per hectare for the species group 3, $N$ total tree number per hectare for all species, $D$ diameter class mean (centimeters), class width $=5 \mathrm{~cm}, B A$ stand basal area (square meters per hectare), $q q$ factor connected with the optimum distribution

\section{References}

Alexander RR, Edminster CB (1977) Uneven-aged management of old growth spruce-fir forests: cutting methods and stand structure goals for the initial entry. USDA For Serv 186:1-13

Appanah S, Turnbull JW (eds) (1998) A review of dipterocarps. Taxonomy, ecology and silviculture. CIFOR, Bogor, p 220

Biber P, Weyerhaeuser H (1999) Numerical methods for characterizing structure and diversity applied to a natural tropical forest and to an even aged Teak stand. In: Mies E (ed) Natural and socioeconomic analysis and modelling of forest and agroforestry systems in Southeast Asia. Zentralstelle für Ernährung und Landwirtschaft, Feldafing, pp 83-104

Bowles IA, Rice RE, Mittermeier RA, da Fonseca GAB (1998) Logging and tropical forest conservation. Science 280:1899-1900

Buongiorno J, Michie BR (1980) A matrix model of uneven-aged forest management. For Sci 26:609-625

Chevrou RB (1990) De Liocourt's law and the truncated law. Can J For Res 20:1933-1946

Con TV (1991) Research on the application ability of mathematical simulation for investigation of structural and dynamic properties of dry dipterocarp forest in Central Highland of Vietnam. Ph.D. dissertation, Forest Science Institute of Vietnam, Hanoi, 118p (in Vietnamese)

Dak Lak Hydrography and Meterology Station (2007) Report about Climate in the Dak Lak Province in the period 2001-2006. 32p (in Vietnamese)

Diep, D. Q., 1993. Contribute to study on natural regeneration process of the dipterocarp forest in Easup area, Dak Lak province, Vietnam. $\mathrm{Ph} . \mathrm{D}$. dissertation, Forest Science Institute of Vietnam, Hanoi, $122 \mathrm{p}$ (in Vietnamese)
Dong HS (2002) Broad-leaf deciduous forests and sustainable forest management in South Vietnam. Science and Technology, Hanoi, p 251, in Vietnamese

Flury PH (1929) Ueber den Aufbau des Plenterwaldes. Eidg Anst Forstl Versuchswes Mitt Bd 15:305-340, in German

Huth A, Ditzer T (2001) Long-term impacts of logging in a tropical rain forest - a simulation study. For Ecol Manage 142:33-51

Huth A, Tietjen B (2007) Management strategies for tropical rain forests: results of ecological models and requirements for ecological-economic modelling. Ecol Econ 62:207-215

Huy B (2007) Applications of sustainable forest model (SFM) in community forest management (CFM) for stable timber harvesting and usage in natural forests. http:/www.socialforestry.org.vn/ English.htm

Köhler P, Huth A (2004) Simulation growth dynamics in a South-East Asian rainforest threatened by recruitment shortage and tree harvesting. Clim Chang 67:95-117

Kolbe AE, Buongiorno J, Vasievich M (1999) Geographic extension of an even-aged, multi-species matrix growth model for northern hardwood forests. Ecol Model 121:235-353

Kürpick P, Kürpick U, Huth A (1997) The influence of logging on a Malaysian Dipterocarp rain forest: a study using a forest gap model. J Theor Biol 185:47-54

Landsberg JJ (2003) Modelling forest ecosystems: state of the art, challenges, and future directions. Can J For Res 33:385-397

Liang J, Buongiorno J, Monserud RA (2005) Estimation and application of a growth and yield model for uneven-aged mixed conifer stands in California. Int For Rev 7:101-112

Lin CR, Buongiorno J, Prestemon J, Skog K (1998) Growth model for uneven-aged loblolly pine stand-simulations and management implications. Research paper FPL-RP-569. U.S.S.A. Forest service, Forest products Laboratory, Madison, $13 \mathrm{p}$ 
Lu H, Buongiorno J (1993) Long- and short-term effects of alternative cutting regimes on economic returns and ecological diversity in mixed-species forest. For Ecol Manage 58:173-192

Monserud RA (2003) Evaluating forest models in a sustainable forest management context. FBMIS 1:35-47

Muys B, Hynynen J, Palahí M, Lexer MJ, Fabrika M, Pretzsch H, Gillet F, Briceño E, Nabuurs GJ, Kint V (2010) Simulation tools for decision support to adaptive forest management in Europe. For Syst 19:86-99

Nguyen TT (2009) Modelling growth and yield of dipterocarp forests in Central Highlands of Vietnam. Ph.D. dissertation, Technische Universität München, $167 \mathrm{p}$

Porté A, Bartelink HH (2002) Modeling mixed forest growth: a review of models for forest management. Ecol Model 150:141-188

Pretzsch H (2009) Forest dynamics, growth and yield: from measurement to model. Springer, Berlin, $664 \mathrm{p}$

Pretzsch H, Schütze G (2009) Trangressive overyielding in mixed compared with pure stands of Norway spruce and European beech in Central Europe: evidence on stand level and explanation on individual tree level. Eur J For Res 128:183-204

Pretzsch H, Biber P, Durský J (2002) The single tree-based stand simulator SILVA: construction, application and evaluation. For Ecol Manage 162:3-21

Pretzsch H, Grote R, Reineking B, Rötzer T, Seifert S (2008) Models for forest ecosystem management: a European perspective. Ann Bot 101:1065-1087

Puettmann KJ, Coates KD, Messier CH (2009) A critique of silviculture. Managing for complexity. Island, Washington, DC, p 188
Sac HV (1984) Dipterocarp forest production and business in Central Highlands of Vietnam. Vietnam For J 7:26-35, in Vietnamese

Schütz JP (2001) Der Plenterwald und weitere Formen strukturierter und gemischter Wälder. Parey, Berlin

Schütz JP (2006) Modelling the demographic sustainability of pure beech plenter forests in Eastern Germany. Ann For Sci 63:93-100

Sist P, Picard N, Gourlet-Fleury S (2003) Sustainable cutting cycle and yields in a lowland mixed dipterocarp forest of Borneo. Ann For Sci 60:803-814

Sterman JD (2000) Business dynamics: systems thinking and modelling for a complex world. Massachusetts Institute of Technology Sloan School of Management, Cambridge, 1008 pp

Usher MB (1969) A matrix model for forest management. Biometrics 25:309-315

Vanclay JK, Skovsgaard JP (1997) Evaluating forest growth models. Ecol Model 98:1-12

Ventana Systems, Inc (2011) Vensim. Online at http://www.vensim. com/. Last access 24 Oct 2011

Weetman G (2005) Partial cutting in the boreal: some concerns, its history and its place in management. Lecture on workshop "Partial cutting in the eastern boreal forest: current knowledge and perspectives". Univ of Quebéc at Temiskaming UQAT, Rouyn-Noranda, UBC Vancouver, $29 \mathrm{p}$

Zhao D, Borders B, Wilson M (2004) Individual-tree diameter growth and mortality models for bottomland mixed-species hardwood stands in the lower Mississippi alluvial valley. For Ecol Manage 199:307-322 